REM WORKING PAPER SERIES

\title{
The Relationship between Fiscal and Current Account Imbalances in OECD Economies
}

António Afonso, Philemon Kwame Opoku

\section{REM Working Paper 061-2018}

November 2018

\section{REM - Research in Economics and Mathematics \\ Rua Miguel Lúpi 20, \\ 1249-078 Lisboa, \\ Portugal}

ISSN 2184-108X

Any opinions expressed are those of the authors and not those of REM. Short, up to two paragraphs can be cited provided that full credit is given to the authors.

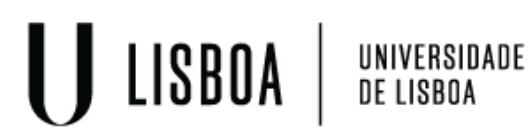




\title{
THE RELATIONSHIP BETWEEN FISCAL AND CURRENT ACCOUNT IMBALANCES IN OECD ECONOMIES*
}

\author{
António Afonso\$, Philemon Kwame Opoku\#
}

November 2018

\begin{abstract}
This study re-examines the nexus between the fiscal balance and the current account balance for 18 OECD countries for the period 1995Q1 to 2018Q1 using panel cointegration, and panel vector autoregressive (VAR) methods. Our results indicate that a strengthening in the fiscal balance by one percentage point of GDP leads to an improvement in the current account balance of about 0.1-0.3 percentage point of GDP. On the other hand, an increase in real government consumption generally leads to a deterioration in the current account balance. The impact of the real effective exchange rate is not statistically significant. The findings also confirm that there is a long-run relationship between the fiscal balance and the current account balance.
\end{abstract}

KEYwORDS: Fiscal imbalances, Current account, Twin-deficit, Panel analysis.

JEL CODES: C32, C40, E62, H62.

\footnotetext{
* The opinions expressed herein are those of the authors and do not necessarily those of their employers.

\$ISEG-UL - Universidade de Lisboa; REM - Research in Economics and Mathematics, UECE - Research Unit on Complexity and Economics. R. Miguel Lupi 20, 1249-078 Lisbon, Portugal. UECE is supported by FCT (Fundação para a Ciência e a Tecnologia, Portugal). email: aafonso@iseg.utl.pt.

\# ISEG-UL - Universidade de Lisboa. email: philemon.kwame.opoku@aln.iseg.ulisboa.pt
} 


\section{INTRODUCTION}

Recently, there has been a worsening of the fiscal and current account positions of several economies worldwide be it developed or developing one. The persistent behaviour of such imbalances has become a pain in the neck of policy makers as these excessive current account deficits have often resulted in a long-run insolvency of most of these economies.

The current account is one of the main indicators of external imbalance of global economics, especially when one considers the economies of countries like the United States. Several economists in attempt to fully understand the possible causes of the recent global financial and economic crisis of 2007-2009, have examined several indicators including a possible contribution of global imbalances towards the spread of the crisis.

The Euro Area (EA) crisis highlighted the need to improve macroeconomic surveillance in the European Union not only with regard to the nature of macroeconomic imbalances but also with regard to institutional framework (Afonso et. al, 2018). These reasons have rekindled the debate and in essence called for the need to re-look at the relationship between the fiscal imbalance and current account imbalances, which is often referred to in the literature as the "Twin deficits hypothesis (TDH)".

The "TDH" postulate that an increase (decrease) in the fiscal balance, otherwise known as the budget balance causes an increase (decrease) in the current account balance respectively. Higher amounts of deficits may render the general government insolvent and thereby crippling its ability to stabilize the public debt and settle those debts when due. Therefore, quite a number of countries have attempted to consider the extent to which fiscal adjustments programs can help resolve such imbalances. This has been the case of several European economics such as Greece, Italy, Ireland, Portugal and Spain.

In view of the fact that the linkage between the fiscal balance and the current account balance could be explained by a number of mechanisms, there is still a considerable controversy among several economist, with conflicting results arising from different econometric methodologies and techniques. The sign and the size of the effect of the budget balance changes on the external accounts vary substantially across studies (Afonso et al., 2018). Interestingly, there is still no consensus on the issue of whether the fiscal balance causes the current account balance or vice versa. More importantly, the issue of causality has been the central point of the debate over the last decade. During the 1980s and 90s, the "twin deficit hypothesis" initially proposed to explain the large or growing current account deficits of the United States, was generally seen as invalid proposition as a result of the lack of empirical evidence suggesting a one-to-one association between the fiscal balance and the current account balance. Studies that 
have examined this linkage among other factors have supported this claim and have argued that even in cases where such a linkage was statistically significant, the association was considerably less than one-to-one relationship (Corsetti and Muller, 2006; Normadin, 1999).

Most recent studies of the linkage between these two balances (imbalances) broadly agree that there is a close nexus between the fiscal balance and current account balance and that causality runs from the fiscal balance to the current account balance, as implied by most standard macroeconomics models such as the Mundell-Fleming model and the Keynesian absorption theory.

Moreover, these studies have pointed out that such a relationship differs in the short-run and in the long-run (Normadin, 1999). Further studies such as Kim and Roubini (2008), provide evidence that higher budget deficits in the United Sates have rather lowered its external deficits, hence, suggesting a "twin divergence", when the endogenous movements of the fiscal and current account deficit are considered. In view of such mixed findings produced by several econometric techniques and methodological approaches of previous empirical studies on this subject, there isn't any consensus among economist on the causal nexus between the fiscal balance and the current account balance.

Although, there are several studies on this topic, they seem not to tell a full story. Therefore, we propose to fill such a gap and adopts a holistic approach in understanding the linkage between the fiscal balance and the current account balance. The empirical investigation is conducted using a number of econometrics techniques such as panel cointegration analysis, panel regressions, panel VAR and a panel Granger causality test on a quarterly dataset for 18 countries (European and OECD countries) for the period of 1995Q1 to 2018Q1. This study is close to a recent study by Abass et al. (2011).

The findings yielded estimated coefficients of around 0.1-0.3, on average, in the panel regressions and panel VAR. These results suggest that there is a linkage between the fiscal balance and the current account balance, but the association is far less than one-to-one. The impact of the real exchange rate appears insignificant. The Granger's causality test indicates a bi-directional causality. These results are in line with other findings in the literature regarding the TDH, which will be discussed in the empirical review.

The remainder of this paper is organized as follows. Section two reviews the related literature. Section three presents the theoretical framework. Section three presents the theoretical framework. Section four describes the econometric strategy and the data set. Section five reports the empirical analysis. Section six is the conclusion. 


\section{LITERATURE}

On the empirical front, a vast number of studies in empirical macroeconomics have used several methods such as cointegration analysis, ordinary least squares regression analysis (OLS), Granger causality tests, and VAR estimations among others to study the causal nexus between the fiscal balance and the current account balance. Amid these, the most widely used method in the literature in examining the linkage between the FB and CA balance is cointegration analysis (Bacham, 1992). Evidence from the majority of such studies suggest that an increase in the FD worsens the CA balance. Earlier work, such as Bernheim (1987), and Holtham and Hooper (1988), used single equation models and found evidence that supports the TDH.

Khalid and Guan (1998), using a sample of five developed and five developing countries, found evidence of no cointegration between the fiscal balance and the current account balance in developed countries, but a non-rejection of such a long-run relationship in developing countries. They also found different results from the causality test.

Since different econometric methods and datasets have yielded mixed results, researchers of the last few years have used more advanced techniques in examining the relationship between these two balances (imbalances). Recent studies using cointegration analysis have tried to account for the existence of structural breaks in order to more accurately identify the long-run relationship between the FB and the CA (Bagnai, 2006). There has also been an inclusion of other factors such as the real effective exchange rate (REER) in the cointegration specification (see Afonso and Rault, 2009) in order to properly account for the effect of REER on the association between FB and CA.

Studies that have used panel regressions are relatively small and such studies have mostly produced coefficients of between 0.1-0.7 percent of GDP. Mohammadi (2004) finds, for a sample of 63 countries that a one-percent of GDP increase in government spending leads to the worsening of the current account by 0.3-0.43 percent of GDP if the spending is tax-financed, and by 0.4-0.72 percent of GDP if bond financed. Kennedy and Slok (2005) also find, for a sample of 14 OECD countries, that for a one-percent increase in the government budget balance, the current account improves by about 0.3 percent of GDP, once indicators of structural policies are included. Moreover, that the impact of the real effective exchange rate on such an association is marginal.

Recent studies that used VAR models such as Kim and Roubini (2004) found evidence to support the TDH hypothesis. Enders and Lee (1990) used VAR models but found no significant association between the FD and the CAD. Beetsma et al (2007), Corsetti and Muller (2006), all 
reported a negative relationship between the FB and the CA balance. Monacelli and Perotti (2007), Kim and Roubini (2008), Abbas et al. (2011), which used a VAR method of estimation, all resorted to using the log of real government consumption or expenditure, as such a measure is the least impacted measure by the changes in gross domestic product (GDP) in comparison to other measures. Abbas et al. (2011), reported an estimated coefficient ranging between 0.30.5 percent of GDP.

Hence, even for similar methodologies and techniques, the results and conclusions are generally mixed.

\section{THEORETICAL FRAMEWORK}

The causal nexus between the fiscal imbalance and the current account imbalance can generally be exemplified by the following well-known identities in Eq. (2), (which relates the current account balance $(\mathrm{X}(\varepsilon)-\mathrm{M}(\varepsilon))$ to the fiscal balance (T-G) through the difference between private saving and investment) obtained after rearranging Eq. (1):

(1) $Y_{t}=C_{t}+I_{t}+G_{t}+X_{t}-M_{t}$,

$$
C A_{t}=X(\varepsilon)_{t}-M(Y, \varepsilon)_{t}=Y_{t}-C_{t}-G_{t}-I_{t}=S_{t}-I_{t}
$$

where $C A_{t}$ is the current account, $X(\varepsilon)_{t}$ is the export of goods and services (decreasing in the real exchange rate, $\varepsilon$, where a higher $\varepsilon$ denotes an appreciation), $M(\varepsilon)_{t}$ is the import of goods and services (increasing in $\varepsilon$ and in national income, $Y_{t}$ ), $C_{t}$ is private consumption, $G_{t}$ is public consumption and $S_{t}$ and $I_{t}$ are savings and investment respectively. The relation in Equation (2) generally suggest that the current account $\left(C A_{t}\right)$ is directly related to the savings $\left(S_{t}\right)$ and investments $\left(I_{t}\right)$ in the economy, hence, policies promoting investment have an adverse effect on the CA, whiles policies that seeks to reduce private and public consumption have a positive impact on the CA, as they tend to increase national savings.

Equation (2) could be further decomposed into Equation (3) below, to distinguish between private and public savings:

(3) $C A_{t}=X(\varepsilon)_{t}-M(Y, \varepsilon)_{t}=\left(Y_{t}-T_{t}-C_{t}\right)+\left(T_{t}-G_{t}\right)-I_{t}=S_{t}^{G}-I_{t}^{G}+S_{t}^{P}-I_{t}^{P}$.

In Equation (3), $S^{G}$ and $I^{G}$ are government savings and investment respectively, such that $S^{G}-I^{G}$ corresponds to the fiscal balance (if there are no government transfers to the private sector), and is equivalent to the difference between tax revenue, $T_{t}$, and expenditures, $G_{t}$. Similarly, $S^{p}$ and $I^{P}$ are private savings and investment such that $S^{p}-I^{P}$ corresponds to income less taxes (disposable income $(Y-T)$ ) and private consumption $(C)$. Equation (3) 
shows that if private savings, $S^{p}$ is roughly equal to private investment, $I^{P}$, then the external account and the fiscal balance are interrelated.

The argument often presented is that the fiscal balance and the external balance are somewhat positively and strongly related and have become widely known as the "twin deficit hypothesis (TDH)'". Theoretically, there are four possible mechanisms that could explain the causal relationship between the fiscal balance (FB) and the current account balance (CA) as described by equation (3).

The first mechanism which is in accordance with most standard macroeconomic models (such as Keynesian absorption theory and the Mundell-Fleming model) postulates that an increase in the fiscal deficit, should have an adverse effect on the current account balance. Thus, in a Mundell-Fleming Framework, with a flexible exchange rate regime, an increase in the fiscal deficit leads to an increase in aggregate demand and an increase in the real domestic interest rate. Depending on the degree of openness of the economy in question, such higher interest rates attracts foreign capital and causes an appreciation of the domestic currency, resulting in a deterioration of the current account balance (Salvatore, 2006; Trachanas \& Katrakilidis, 2013; Xie \& Chen, 2014). Under a fixed exchange rate regime, a fiscal boost generates a higher real income and prices, and this deteriorates the current account balance (Anoruo \& Ramchander, 1998). The argument of the Keynesian absorption theory is that an increase in the fiscal deficit (FD) would induce a domestic absorption (an expansion of aggregate demand) which could lead to an import expansion thereby worsening the current account deficit (CAD) (Darrat, 1988; Normaddin, 1999; Hatemi \& Sukur, 2002; Ahmad et al., 2015). Hence, this first mechanism suggests a causal relationship that runs from the fiscal deficit to the current account deficit.

However, contrary to the first mechanism where causality runs from the FD to the CAD, the second mechanism known in the literature as the current account targeting hypothesis (CATH) suggests a reverse causality nexus, which runs from the CAD to the FD. The argument is that the authorities of a country may use fiscal policy to adjust its external position. This happens when a deterioration in the CAD results in diminished economic growth, which subsequently leads to a deterioration in the fiscal balance. In this case, the authorities are said to be, in the words of Summers (1988), "targeting the current account deficit".

The third mechanism suggests that the causal nexus between the fiscal deficit and the current account deficit is somehow related to the degree of international capital mobility and to the Feldstein-Horioka (1980) puzzle (see Marinheiro, 2008). If savings and investment are not strongly correlated, thus reflecting high capital mobility, then the FD and the CAD are expected to co-move. Afonso and Rault (2009) stressed this argument that for the TDH to hold, savings 
and investments should not be strongly correlated, implying that increases in private savings may not be sufficient to offset the effects of increased fiscal deficits. Therefore, this mechanism suggests a bi-directional causality that could run from the FD to the CAD, and vice versa.

Finally, contrary to the already discussed traditional Keynesian viewpoint is a mechanism known as "the Ricardian Equivalence Hypothesis (REH)”' of Barro (1974, 1989). Models of such hypothesis suggest that an exogenous increase in the fiscal deficit will be matched by an instantaneous equal increase in private savings, rather than an increase in net foreign borrowing. Thus, consumers perceive an increase in the fiscal deficits as the postponement of higher taxes to the future. Therefore, on a given expenditure path, the substitution of debt for taxes has no effect on aggregate demand nor on interest rates. This hypothesis unlike the previous three discussed mechanisms argues that the fiscal deficit and the current account deficit are not causally related. Therefore, the REH predicts a neutral or no causal relationship between the fiscal and current account deficit.

\section{Econometric Methodology, DAta ANd Model Selection}

\subsection{Econometric methodology}

In the empirical assessment, we conduct a cross-sectional dependence (CSD) test for the panel. The results from the CSD test serve as a guide in choosing the appropriate panel unit root test (PURT). If evidence is found for the existence of CSD, then "second generation" PURT are employed in testing for the integrated properties of the series in the panel. These two tests (CSD and PURT) are used as the basis for conducting the various estimations.

The econometric approach used in this paper includes four types of assessment. The first category examines the long-run relationship between the fiscal balance and the current account balance through the use of a cointegration analysis. Testing for the existence of co-integration among economic variables is an increasingly popular approach to studying long-run economic interrelationships. The literature mostly has used the following linear models in testing the validity of the twin deficits hypothesis in a panel framework:

$$
C A_{i, t}=a_{i}+\beta_{i} F B_{i, t}+u_{i, t}
$$

where the index $i(i=1, \ldots, N)$ denotes the country, the index $t(t=1, \ldots, T)$ indicates the period. The specification in equation (4) above means that we can test for the existence of a long-run relationship by assessing the possible effects of the fiscal balance on the current account balance.

Also, an augmented specification of equation (4) (as in Afonso and Rault, 2013) to capture the effect of the real effective exchange rate (REER) is assessed in the following framework: 


$$
C A_{i, t}=a_{i}+\beta_{i} F B_{i, t}+\delta_{i} R E E R_{i, t}+u_{i, t} .
$$

As already discussed in the literature review, the real effective exchange rate could have a positive or negative impact on the current account balance, hence, its presence in the cointegration analysis cannot be discounted. Although, additional factors such as the degree of trade and financial openness of the economy, exchange rate regime could have an impact on the current account, the main idea here is to concentrate on the FB and on the CA balance. In this study, both equations (4) and (5) were assessed using Westerlund (2007) cointegration test and the coefficients were estimated using the Pesaran (2006) common correlated effects mean group estimator (CCE-MG). The CCE-MG method was chosen as it allows for cross-section dependence which is required in this particular case according to the results of the CSD test. Moreover, the CCE-MG accounts for the presence of unobserved heterogeneity (Eberhardt and Presbitero, 2010).

Secondly, we examine the impact of fiscal balances on the current account balance using panel regressions for 18 OECD countries. The two main variables used in the cointegration analysis (current account balance as percentage of GDP and fiscal balance (net lending/borrowing as a percentage of GDP)) were again used in the panel regressions. A third variable, the real effective exchange was also included, and further estimations were done in similar manner as in equations (4) and (5). The pooled OLS method, also known as the common constant method suggests that there are no differences between the estimated cross-sections $(N=18)$, and its only useful under the hypothesis that the data set is a priori homogeneous, which is not the case in this study.

Therefore, to address this problem of heterogeneity bias, fixed effects (FE) could be used since they capture all effects that are specific to a particular country and vary overtime. A second method that could be used in dealing with unobserved effects in panel data, is the random effects (RE) method, which handles the constant for each cross section as random parameters.

After estimating the equations with the pooled OLS methods, fixed effects method and then, the random effects method, the Hausman test is conducted to identify the most appropriate method among the fixed and the random effect estimators. The dynamic model built is the following one:

$$
C A_{i, t}=a_{0}+a_{i}+\beta_{1} F B_{i, t}+\delta_{1} R E E R_{i, t}+\gamma_{1} C A_{j, t-1}+\left(\sigma_{0}+\sigma_{i}+\beta_{2} F B_{i, t}+\right.
$$

$\left.\delta_{2} R E E R_{i, t}+\gamma_{2} C A_{j, t-1}\right) D_{2008}^{C}+u_{i, t}$, 
where $C A_{i, t}$, denotes the current account balance (\% of GDP), $F B_{i, t}$, denotes the fiscal balance (\% of GDP), $R E E R_{i, t}$, refers to the real effective exchange rate, and $C A_{j, t-1}$, denotes the lagged current account (\% of GDP). $D_{2008}^{C}$ is a crisis dummy taking the value of one in the period after the collapse of the Lehman Brothers in September 2008, and $a_{i}$ and $\sigma_{i}$ are the country specific fixed effects.

The third approach used in our empirical analysis is a panel vector autoregressive model (VAR) in order to understand the dynamic impact of the FB on the CA balance. Due to the difficulty encountered by previous studies in the identification of the exogenous fiscal shocks in order to accurately estimate the impact of FB on the CA, recent empirical studies (Monacelli and Perotti, 2007; Corsetti, Meier and Muller, 2010) in an attempt to deal with the endogeneity problem have used government consumption (as a proxy to the fiscal balance), as this variable is less likely to react to changes in output. In view of this, an investigation is conducted using a VAR model that comprised of the following variables as described in Table 1.

[Table 1]

The variables in Table 1 are in accordance with the manner in which recent studies have estimated the VAR, with the ordering of the variables given in model A. In contrast to recent studies, the variables in model B includes the fiscal balance (FB) instead of the real government consumption (RGC), since the main idea in this study is to focus on the linkage between the fiscal balance (FB) and the current account balance (CA), and the ordering of the variables is as in Model B. The VAR specification is in line with the one used by Beetsma, Giuliodori, and Klaasen (2007), Corsetti and Muller (2006), Monacelii and Perotti (2007), and Abbas et al. (2011), with the description of the endogenous variables in Table 1. The identification scheme is based on a Cholesky decomposition with the following ordering of the variables:

- Model A: [RGDP RGC CA RIR REER].

- Model B: [RGDP FB CA RIR REER].

Each variable in the model is allowed to react contemporaneously with other variables. The ordering of the last two variables in both model one and two are irrelevant as this study is interested in analyzing shocks to the fiscal balance and real government consumption. The implied assumption is that government consumption responds to other variables with a delay of one quarter, hence, the inclusion of the log of real government consumption. The RGDP is included to control for the cyclical component of the fiscal balance. The real interest rate (RIR) is also included to control for monetary policy actions. The CA is the main variable of interest here. 
The model in its structural form is the following:

$$
A_{0} Z_{t}=A_{1} Z_{t-1}+A_{2} Z_{t-2}+\varepsilon_{t},
$$

where $Z_{t}$ denotes the endogenous variables described in Table $1, \varepsilon_{t}$ is a vector of mutually uncorrelated innovations and $A_{i}$ are the coefficient matrices. The reduced form is then:

$$
\begin{aligned}
& y_{t}=a_{10}+a_{11} y_{t-1}+a_{12} x_{t-1}+e_{1 t}, \\
& x_{t}=a_{20}+a_{21} y_{t-1}+a_{22} x_{t-1}+e_{2 t},
\end{aligned}
$$

with the error terms $e_{1 t}$ and $e_{2 t}$ obtained as follows (both are white-noise processes):

$$
\begin{aligned}
& e_{1 t}=\left(u_{y t}+\beta_{12} u_{x t}\right) /\left(1-\beta_{12} \beta_{21}\right), \\
& e_{2 t}=\left(u_{x t}+\beta_{21} u_{y t}\right) /\left(1-\beta_{12} \beta_{21}\right) .
\end{aligned}
$$

The results of the VAR model are presented in the form of the dynamic impulse response of the other three variables to an increase in either the log of real government consumption or the fiscal balance.

The last approach adopted in this study is the Granger (1969) causality tests for fiscal balance and the current account balance. The test was carried on the basis of the following four hypothesis:

i) FB Granger cause the CA.

ii) CA Granger cause the FB.

iii) Bi-directional causality.

iv) $\quad \mathrm{CA}$ and $\mathrm{FB}$ are independent.

The conventional Granger causality test involves running the following two regressions (with the null hypothesis: $x_{t}$ does not Granger cause $y_{t}$ ):

$$
\begin{aligned}
& y_{t}=\sum_{i=1}^{m} a_{i} y_{t-1}+\sum_{j=1}^{n} b_{j} x_{t-1}+e_{t}, \\
& y=\sum_{n}^{m} a_{i} y_{t-i}+e_{t},
\end{aligned}
$$

where in this particular study $x_{t}$ represents the FB and $y_{t}$ represents the CA balance.

\subsection{Data, Variable Description and Stylized Facts}

The data used in this study were collected from a number of databases including OECD database, Eurostat, FRED, and IMF database and are of quarterly frequency, covering the period 1995Q1-2018Q1 for 18 OECD countries: Australia (AUS), Austria (OST), Belgium (BEL), Canada (CAN), Denmark (DEN), Finland (FIN), France (FRA), Germany (DEU), Greece (GRE), Ireland (IRE), Italy (ITA), Luxembourg (LUX), Netherlands (NED), Portugal (POR), Spain (ESP), Sweden (SWE), United Kingdom (UKA), and the United States (USA). These countries were selected in order to construct a panel that possesses different characteristics or time series properties. There are many advantages of using panel data and is 
considered to be a very efficient analytical method for empirical work. Panel data allow for more information, more variability, less collinearity, more degrees of freedom and efficiency (Balgati, 2005). The choice of quarterly data over annual data is to appropriately capture the timely response of fiscal balance and government consumption to changes in output.

The variables under consideration are the current account balance (CA) as a percentage of GDP, the fiscal balance (FB) as a percentage of GDP, the real gross domestic product (RGDP), the real government consumption (RGC), real interest rates (RIR), and real effective exchange rate (REER), for all the 18 countries over the examined period. The fiscal balance (FB) and the current account balance (CA) are the two main variables used for the panel regressions, panel cointegration and Granger causality test, with the inclusion of REER when desired. The variables used for the panel VAR are the current account (CA) as a percentage of GDP, the log of real gross domestic product (RGDP), log of real government consumption (RGC) or the fiscal balance (FB), real interest rate (RIR) and the log of real effective exchange rate (REER).

All the variables used were obtained as seasonally adjusted variables from their source. The RGDP variable was constructed using the nominal GDP and the GDP deflator for each country. RGC was constructed using the private consumption deflator. The RIR is the short-term nominal interest rate adjusted for by the inflation rate for each particular country. The REER was obtained directly from their sources. A detailed descriptive statistic (individual and common samples) as well as the correlation among the variables can be found in Appendix 1 .

It could be noticed that the correlation between the fiscal balance (FB) and current account balance (CA) is around 0.4 for the entire panel, which is somehow moderate. An inspection of the charts (in Appendix A) of the fiscal balance (FB), current account balance (CA) and the real exchange rate provides more highlights about some of the stylized facts as known in the literature regarding the linkage between these variables. From those graphs, one could identify not just the frequency but also a parallel movement of the deteriorations (improvements) in the current account balance and the fiscal balance, as well as the impact on the real effective exchange rate.

\subsection{Cross-Sectional Dependence Test (CSD)}

Testing for the cross-sectional dependence is crucial in the choice of the appropriate estimators (Bai and Kao, 2006). Most “first generation" test assume cross-section independence, therefore, as some sort of a robustness check, the Pesaran (2004) test for error cross-sectional dependence $\left(C D_{p}\right)$ is employed. The $C D_{p}$ test is based on an average of pairwise correlation coefficient of OLS residuals from individual regressions (Pesaran, 2012). $C D_{p}$ 
works with unbalanced panel as is the case for our study, and more importantly, is robust to single and multiple structural breaks in the slope coefficients and the error variances of the individual regressions. The test estimates $\mathrm{N}^{*}(\mathrm{~N}-1)$ correlations between countries $\mathrm{i}=1$, and all other countries, $\mathrm{N}-1\left(\mathrm{~N}=18\right.$ in this case). The $C D_{p}$ statistic is calculated as follows:

$$
C D_{p}=\sqrt{\frac{2 T}{N(N-1)}}\left(\sum_{t=1}^{N-1} \sum_{j=i+1}^{N} \hat{\rho}_{i j}\right) .
$$

The results of the test are depicted in Table 2, and indicate that the null hypothesis of crosssectional independencies is rejected for most series in the panel, with a moderate correlation coefficient.

[Table 2]

\subsection{Panel Unit Root Test}

With the CSD test result indicating the presence of cross-sectional dependence, there is a high tendency for the "first generation" PURT to reject the null hypothesis of a unit root. In view of this, a "second generation" PURT, Pesaran (2007) is applied (results of the $1^{\text {st }}$ generation test, Maddala and $\mathrm{Wu},(1999)$ are available on request). This test is based on the mean of the individual ADF t-statistics of each unit in the panel and is able to eliminate the presence of cross-section dependence by augmenting the ADF regressions with the lagged cross-sectional mean and its first differences of the individual series to capture CSD by a single factor model. The test allows for heterogeneity in the autoregressive coefficients of the DickyFuller regressions and allows for the presence of single unobserved common factor with heterogenous factor loadings in the data. The result of this test is likely to be influenced by the chosen number of lag length, therefore, the ideal lag length is selected for using the Akaike Information Criteria (AIC). Moreover, results are shown for the lag bandwidth 0-4.

The tests are estimated both in levels and first differences, with and without a trend respectively. The test produced mixed results among all the variables under consideration, with four (CA, FB, REER, RIR) out of the six-variable series (CA, FB, REER, RIR, RGDP, RGC) being stationary in levels and in first differences, with and without trend. The other variables were stationary in their first differences. The PURT results are quite sensitive to the number of lags chosen. However, all the series were found to be stationary when they were considered in their first difference, hence, they could be described in general as integrated of order one, I (1). The test results can be found in Table 3 .

[Table 3] 


\section{EMPIRICAL ANALYSIS}

\subsection{Cointegration Results}

Regarding the cointegration analysis, the Westerlund (2007) error correction based cointegration rejected the null hypothesis of no cointegration at the $1 \%$ significance level in each of the specification (restricted and unrestricted case, with a constant, and with a constant and a trend respectively) even in cases where the short-run dynamics were held fixed. Similar results were obtained when the robust p-values were considered. The cointegration test results are shown Table 4. The result of the test of no cointegration, with the inclusion of the real effective exchange rate (as indicated by equation (6)) was not different from the first result, conducted on the basis of equation (4). These results provide a clear evidence that the fiscal balance and the current are cointegrated, and as such, they have a long-run relationship.

[Table 4]

With evidence from the cointegration result suggesting long-run relation between the FB and CA, the magnitude of the coefficient was estimated using the Cross Correlated Effects and the Common Correlated Effects Mean Group (CCE-MG) estimation procedures developed by Pesaran (2006). The results from Table 5 indicate a cointegration coefficient of 0.20 when estimation was done on the basis of equation (4). The result didn't change much (coefficient of 0.24) when the real effective exchange rate was included as in equation (5). These results provide evidence that a long-run relationship exists but it is small in terms of magnitude.

[Table 5]

\subsection{Granger Causality Test}

The results of the Granger causality test depicted in Table 6 suggest a bi-directional causality from both FB and CA, irrespective of the number of lags chosen. This result implies that these two balances could be linked either through the first mechanism, thus a Keynesian hypothesis or via the third mechanism as discussed in the earlier in the paper. In this case it is not sufficient for the government to cut the budget deficit in order to decrease the current account deficit (Kalou and Paleologou, 2012). Hence, other policy actions such as exchange rate and interest rate policy, and export promotion policies would be needed.

[Table 6]

\subsection{Panel Regression Results}

The result of the Hausman test (Tables 7,8) under the null hypothesis that "the random effect method is appropriate", indicated that the fixed effect method is the appropriate method of estimation, hence, the panel regressions were conducted using fixed effect method. Estimations were done using traditional panel data models and a dynamic model characterized by the 
presence of a lagged current account (\% of GDP) variable among the regressors. Also included in the model is a constant term, a year dummy and country fixed effects ${ }^{1}$.

[Table 7]

[Table 8]

Tables 7 and 8 provide an overview of different estimated regression results of the current account on the fiscal balance. The findings indicate an estimated regression's coefficient ranging from 0.15 to 0.65 percent points of GDP. The regression results obtained using fixed effects indicate that, on average, a strengthening in the fiscal balance (\% of GDP) of one percentage point is associated with about 0.29 percentage point improvement in the current account ( $\%$ of GDP). The inclusion of a lagged current account and a year dummy (both statistically significant at $1 \%$ ) resulted in a coefficient of 0.15 percentage point. This indicates effect of the crisis period on the relationship between the current account and the fiscal balance. Thus, the crisis period minimized the exposure of the current account to the fiscal balance. The estimation results also suggest that an appreciation in the exchange rate leads to a deterioration in the current account of about 0.04 percentage point, and this is statistically significant at one percent level.

\subsection{Panel Var Results}

The results of the Var model are analysed in the form of impulse response functions and variance decompositions for both model A (shock to real government consumption) and model B (shock to fiscal balances).

\section{i) Model A}

The impulse responses (Figure 1) for the panel of 18 countries indicates that following a unit shock to real government consumption, the CA deteriorates in the $1^{\text {st }}$ quarter and gradually increases after the $2^{\text {nd }}$ quarter. The RIR falls significantly till the $3^{\text {rd }}$ quarter where it rises and then again retreat in the $4^{\text {th }}$ quarter. Additionally, the REER rises from the first quarter of the shock, remains stable till quarter 3, and then takes a downward trend. RGDP is also characterized by high fluctuations, initially increasing till quarter 2 where it falls and then rise again till quarter 4. The accumulated effects are also shown in Figure 2. The CA deteriorates further until the third quarter where it begins to rise, then remains stable from the fourth quarter till the fifth quarter and thereafter declines. RIR remains stable in the first and the second quarter, then embarks on a continuous decline. The RGDP is seen to be continuously rising upon impact of the shock. The REER seems stable on average. These results are somehow

\footnotetext{
${ }^{1}$ The addition of the lagged current account (\% of GDP) is able to control for year to year persistence in the current account (Abbas et al., 2011).
} 
consistent with the findings of Abass et al. (2011), where the so called "Twin Deficit Hypothesis" is confirmed, though there are differences in the duration.

FIGURE 1 - Impulse Responses of RGDP, CA, RIR, REER to one-unit shock to RGC. Response to Cholesky One S.D. (d.f. adjusted) Innovations - 2 S.E. Response of $\mathrm{D}(\mathrm{LNRGDP})$ to $\mathrm{D}(\mathrm{LNRGC})$ Response of $\mathrm{D}(\mathrm{CA})$ to $\mathrm{D}(\mathrm{LNRGC})$
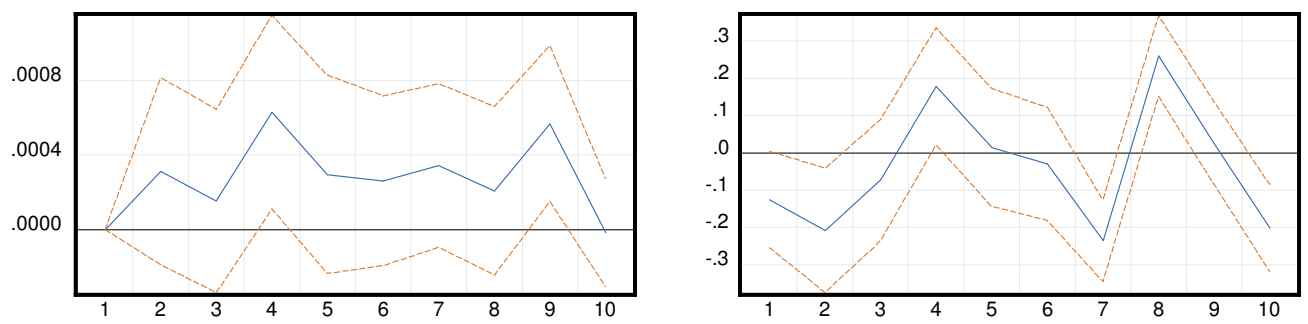

Response of $\mathrm{D}(\mathrm{RIR})$ to $\mathrm{D}(\mathrm{LNRGC})$ Response of $\mathrm{D}(\mathrm{LNREER})$ to $\mathrm{D}(\mathrm{LNRGC})$
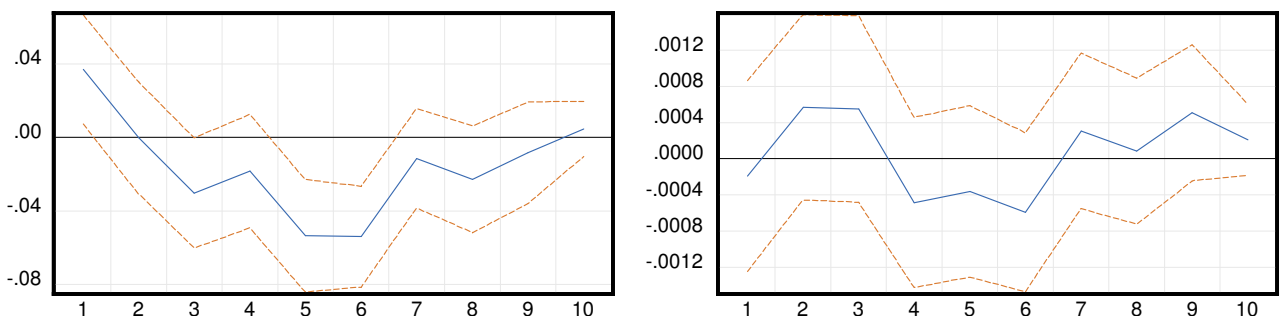

FIGURE 2 - Accumulated Responses of RGDP, CA, RIR, REER to one-unit shock to RGC. Accumulated Response to Cholesky One S.D. (d.f. adjusted) Innovations \pm 2 S.E. Accumulated Response of DLNRGDP to DLNRGCE Accumulated Response of DCA to DLNRGCE
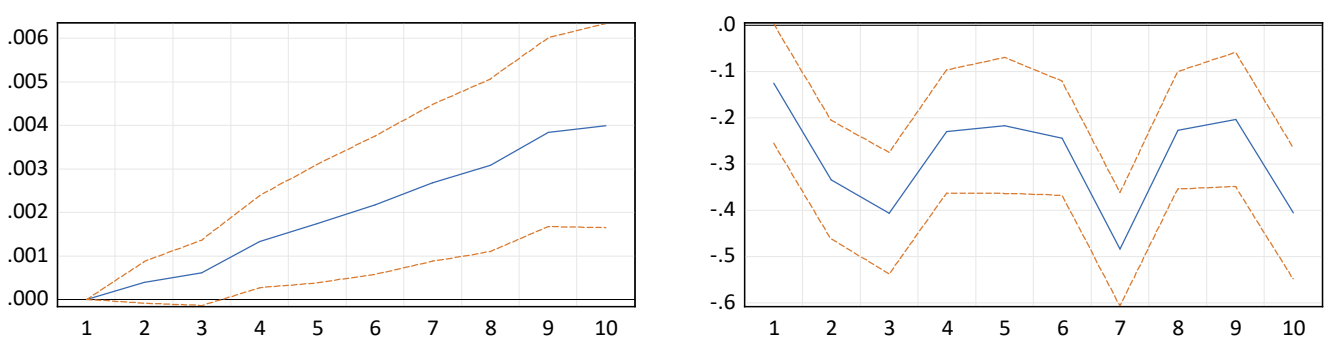

Accumulated Response of DRIR to DLNRGCE Accumulated Response of DLNREER to DLNRGCE
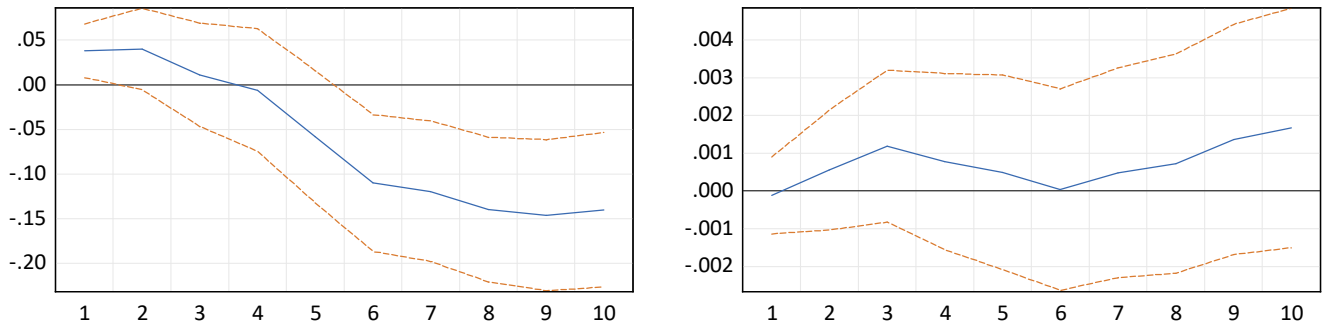

ii) Variance decomposition of Model A

Appendix Table B1 provides the results of the forecast error variance in percentages, for evaluating the proportion of the variations in RGDP, CA, RIR, and REER to a unit shock or 
innovation to all the endogenous variables. With respect to the main variable under consideration in this study (CA), about $99 \%$ of the forecast error variance is explained by the variable itself (CA), gradually decreasing to $93 \%$ in the 4th quarter and beyond. Shocks to the RGC accounts for 0.2 to $0.6 \%$ of the variation in the CA, in the first and second quarter, increasing to about $2 \%$ by the 10th quarter. Other variables have strong exogenous (weak endogenous) influence on the $\mathrm{CA}$, and this could be as a result of the year to year persistence of the current account balance.

iii) Model B

When a unit shock is given to the fiscal balance, the impulse responses (Figure 3) also shows that the CA declines from the 1 st quarter till the $3^{\text {rd }}$ quarter and gradually increases after the 4 th quarter. The RIR unlike as it was in model A, increases significantly till the $2^{\text {nd }}$ quarter where it falls and then picks up again from the 3rd quarter onwards. Moreover, the REER exhibit huge fluctuations. It rises from the first quarter of the shock, in a similar manner as in model A, and then falls after the second quarter. RGDP is also characterized by huge fluctuations as was the case in Model A. The accumulated effects are shown in Figure 4. The results indicate that upon impact of the shock, CA declines till the second quarter, remains stable on the average till the fourth quarter, then fluctuates over the rest of the period. There is no impact on RGDP until the fourth quarter where it slightly falls and thereafter remains stable on the average. RIR increases in the first and the second quarter, then remains stable afterwards till the eight quarter where it embarks again on an upward trend. The REER slightly increases and then remains stable on the average for the rest of the period. These results, in terms of the response of the CA are somehow similar to that of model A, that the so called "Twin Deficit Hypothesis" is confirmed, though there are differences in the duration as mentioned earlier.

\section{iv) Variance decomposition of Model B}

The results of the forecast error variance in percentages (table III b) for model B aren't much different from that of model A. About $99 \%$ of the forecast error variance of the CA is explained by the variable itself (CA) in the first two quarters, gradually decreasing to $91 \%$ in the 8th quarter and beyond. Just as in model A, other variables have strong exogenous (weak endogenous) influence on the CA. Shocks to the FB accounts for about $0.3 \%$ of the variation in the $\mathrm{CA}$, in the first and second quarter, increasing to about $1 \%$ by the last two quarters. RGDP accounted for about $6 \%$ of the forecast error variance of the CA in the $8^{\text {th }}$ quarter and beyond. 
FIGURE 3 - Impulse Responses of RGDP, CA, RIR, REER to one-unit shock to FB. (Model B)

Response to Cholesky One S.D. (d.f. adjusted) Innovations - 2 S.E.

Response of $\mathrm{D}(\mathrm{LNRGDP})$ to $\mathrm{D}(\mathrm{FB})$

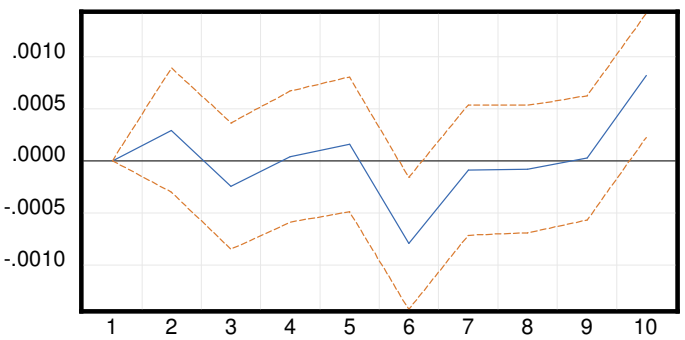

Response of $\mathrm{D}(\mathrm{RIR})$ to $\mathrm{D}(\mathrm{FB})$

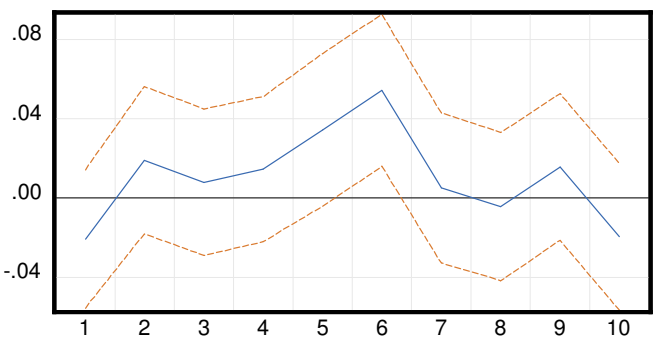

Response of $\mathrm{D}(\mathrm{CA})$ to $\mathrm{D}(\mathrm{FB})$

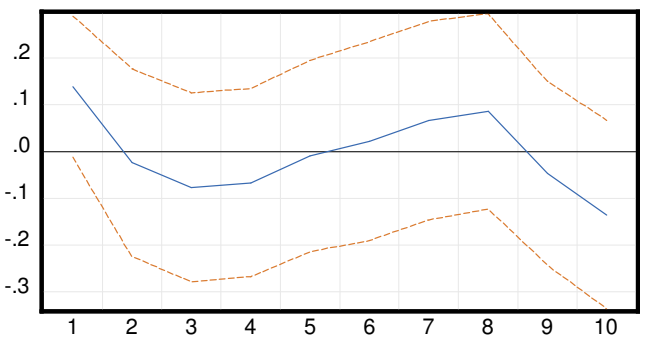

Response of $\mathrm{D}$ (LNREER) to $\mathrm{D}(\mathrm{FB})$

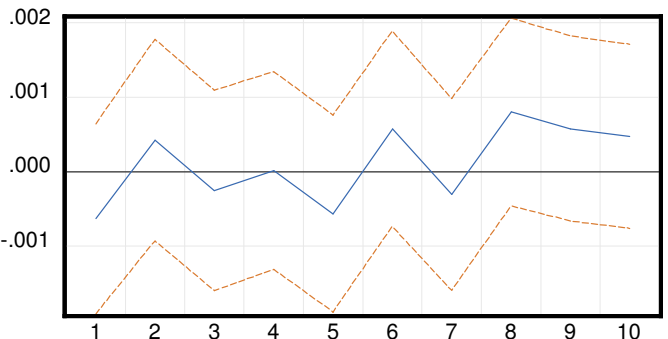

FIGURE 4 - Accumulated Responses of RGDP, CA, RIR, REER to one-unit shock to FB. (Model B)

Accumulated Response to Cholesky One S.D. (d.f. adjusted) Innovations \pm 2 S.E.
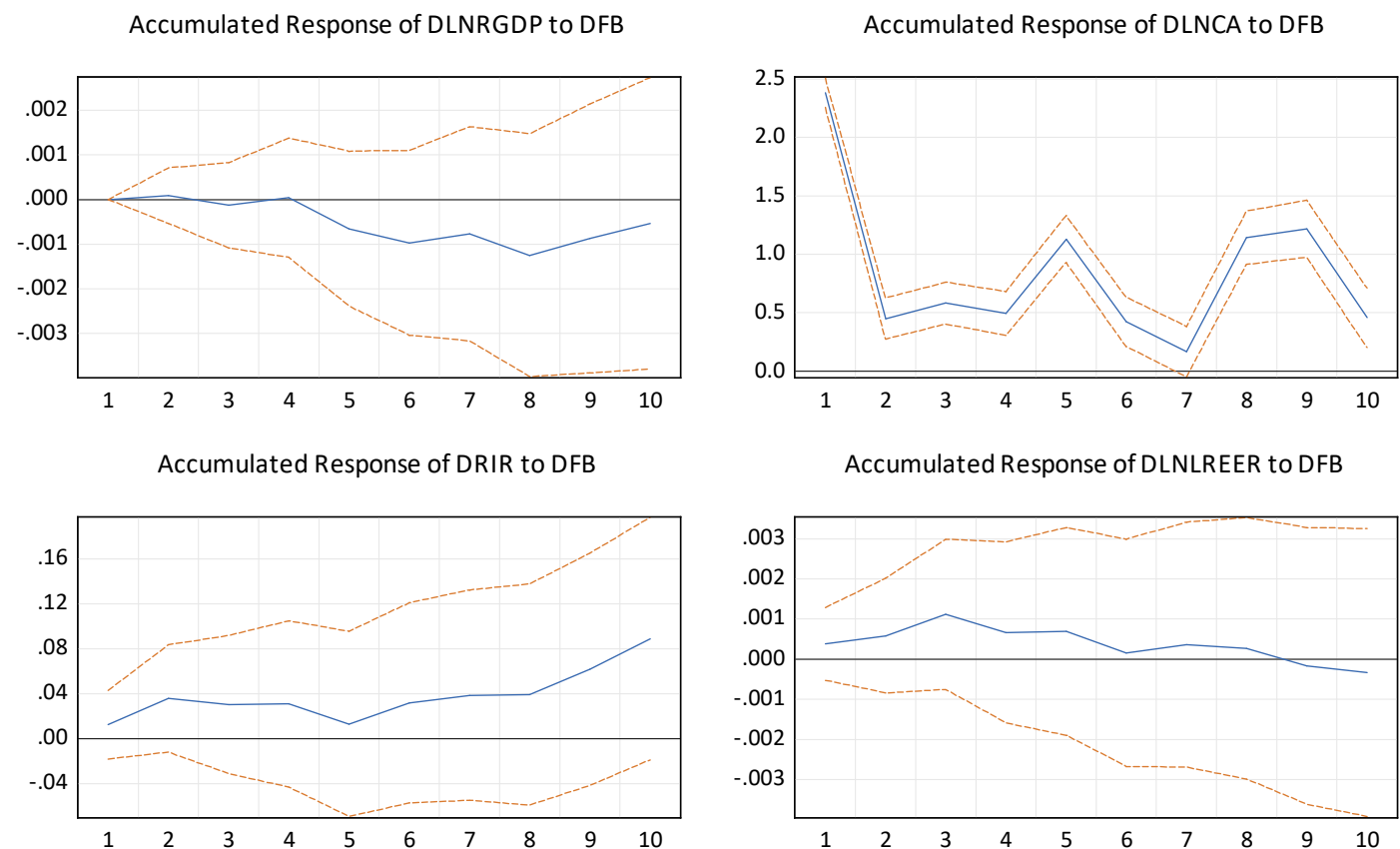


\section{CONCLUSION}

We have studied the linkage between the fiscal balance (imbalance) and the current account balance (imbalance) for a panel of 18 countries, 15 European countries and 3 OECD countries, using quarterly data from 1995Q1 to 2018Q1. In the empirical assessment we used panel estimation methods such as panel cointegration, panel Granger causality test, panel regressions, and the panel VAR methods were employed.

According to our results, we found that there is a long-run relationship between the fiscal balance and the current account balance. However, such an association was found to be not too strong. Thus, the findings from the panel regressions and from the Panel VAR suggest that a fiscal expansion (proxied by an increase in the log of real government consumption) generally leads to a deterioration in the current account balance by 0.2 percentage point of GDP. On the other hand, an improvement in the fiscal balance of one percentage point is associated with about 0.3 percentage point improvement in the current account

The results of this study also showed that the there is a bi-directional causality between the fiscal balance and the current account balance, indicating that savings and investments for this panel of countries may not highly correlated. This means that the linkage between the fiscal balance and current account balance could be explained by the third mechanism discussed previously in the paper. Moreover, the behaviour of the real interest rate, thus, rising significantly after a unit shock to the fiscal balance as shown in figure 2 (Model B), seems to provide evidence in support of the thirds mechanism, that the simple open economy model of Mundell (1963) uses in generating the "Twin Deficit Hypothesis".

We also examined the role of exchange rate in the transmission of fiscal policy shocks to the current account balance. However, this variable did not have a significant impact on the results, indicating a weak exchange rate channel. The inclusion of the real interest rate to account for monetary policy shocks also did not uncover any significant impact for the results.

Finally, we have found evidence supporting the "Twin deficit hypothesis", which is consistent with the results from previous studies.

\section{REFERENCES}

Abbas, S. M. A., Hagbe, J. B., Fatas, A., Mauro, P., Velloso, R. C. (2011). Fiscal Policy and Current Account. IMF working paper 10, 121.

Afonso, A., \& Rault, C. (2009). Budgetary and external imbalances relationship: A panel data diagnostics. CESifo Working Paper, No. 2559, CESifo Group Munich. 
Afonso, A., Huart, F., Jalles, J. T., Stanek, P. (2018). Assessing the sustainability of external imbalances in the European Union. World Econ. 2018; 00:1-29.

Afonso, A., Huart, F., Jalles, J. T., Stanek, P. (2018). Twin Deficits Revisited: A Role for Financial Institutions. REM working paper 031-2018.

Anoruo, E \& Ramchander, S. (1998). Current Account Fiscal Deficits: Evidence from Five Developing Economies of Asia. Journal of Assian Economics. vol. 9(3), pp. 487- 501.

Bagnai, A. (2006). Structural breaks and the twin deficit hypothesis. International Economics and Economic Policy, 3, 137-155.

Bai, J., \& Kao, C. (2006). On the estimation and inference of a panel cointegration method with cross-sectional dependence. In B. H. Baltagi (Ed.), Panel Data Econometrics: Theoretical Contributions and Empirical Applications. Science and Technology.

Barro, R. J. (1989). Ricardian approach to budget deficits. Journal of Economic Perspectives, $3,37-54$.

Beetsma, R., Giuliodori, M., \& Klassen, F. (2007). The Effects of Public Spending Shocks on Trade Balances and Budget Deficits in the European Union. Journal of the European Economic Association, Vol. 6, Nos. 2-3, pp. 414-23.

Bernheim, B. D. (1987). Ricardian equivalence: An evolution of theory and evidence with three 'Comments'. In S. Fisher (Ed.), NBER macroeconomics annual 1987 (pp. 263-315). Cambridge, MA: MIT Press.

Breusch, T., \& Pagan, A. (1980). The Lagrange Multiplier test and its application to model specifications in econometrics. Reviews of Econometrics Studies, 47, 239-253.

Corsetti, G., Muller, G. (2006). Twin deficits: squaring theory, evidence and common sense. Economic Policy 21 (48), 597-638.

Darrat, A. F. (1998). Have Large Budget Deficits Caused Rising Trade Deficits? Southern Economic Journal, 54, 879-887.

Enders, W., Lee, B. (1999). Current account and budget deficits: twins or distant cousins? The Review of Economics and Statistics 72 (3), 373-381.

Engle, R.F., Granger, C.W.J. (1987). Co-integration and error correction: representation, estimation, and testing. Econometrica 55, 251-276.

Feldstein, M., \& Horioka, C. (1980). Domestic savings and international capital flows. The Economic Journal, 90 (June), 314-329.

Grangner, C.W.J., Yoon, G. (2002). Hidden cointegration. Working Paper No. 2002-02. University of California, San Diego. 
Gregory, A. W., \& Hansen, B. E. (1996). Residual-based tests for cointegration in models with regime shifts. Journal of Econometrics, 115, 53-74.

Hatemi, A., \& Shukur, G. (2002). Multivariate-based causality test of twin deficits in the US. Journal of Applied Statistics, 29, 817-824.

Johansen, S. (1988). Statistical analysis of cointegration vectors. Journal of Economic Dynamics and Control, 12,231-254.

Kalou, S., \& Paleologou, S. (2012). The twin deficits hypothesis: Revisiting an EMU country. Journal of Policy Modelling, 34, 230-241.

Kennedy, M., \& Slok, T. (2005). Structural Policy Reforms and External Imbalance. OECD Economics Department Working Papers, No. 415. OECD Publishing, Paris.

Kim, S., \& Roubini, N. (2008). Twin deficit or twin divergence? Fiscal policy, current account, real exchange rate in the U.S. Journal of International Economics, 74. 362-383.

Kwiatowski, D., Phillips, P. C. B., Schmidt, P., \& Shin, Y. (1992). Testing the null hypothesis of stationarity against alternative of a unit root: How sure are we that economic time series have a unit root? Journal of Econometrics, 54,159-178.

Maddala, G. S., \& Wu, S. (1999). A comparative study of unit root tests with panel data and new simple test. Oxford Bulletin of Economics and Statistics, 61, 631-652.

Marinheiro, C. F. (2006). Ricardian Equivalence, Twin Deficits, and the Feldstein-Horioka puzzle in Egypt. GEMF, 7 (May). http://ssrn.com/abstract=1009788.

Mohammadi, H. (2004). Budget Deficits and Current Account Balance: New evidence from panel data. Journal of Economics and Finance, 28 (1), 39-45.

Monacelli, T., \& Peroitti, R. (2007). Fiscal Policy, the Trade Balance, and the Real Exchange Rates: Implications for International Risk Sharing. Universita Bocconi, Milan, Italy.

Mundell, R. (1963). Capital mobility and stabilization policy under fixed and flexible Exchange Rates. Journal of Economics and Political Sciences, 29, 475-85.

Normadin, M. (1999). Budget deficit persistence and the twin deficit hypothesis. Journal of International Economics, 49, 171-193.

Pesaran, B., Pesaran, M.H. (2009). Time series econometrics using Microfit 5.0. Oxford University Press, Oxford.

Pesaran, M. H. (2004). General diagnostic test for cross section dependence in panels. CESifo Working Paper 1229, IZA Discussion Paper 1240.

Phillips, P. C. B., \& Hansen, B. E. (1990). Statistical inference in instrumental variables regression with I (1) processes. Review of Economic studies, 57, 99-125. 
Salvatore, D. (2006). Twin deficits in the G-7 countries and global structural imbalances. Journal of Policy Modelling, 28, 701-712.

Summers, L. (1988). Tax policy and international competitiveness. In Frenkel, J. A. (Ed.), International aspects of fiscal policies (NBER Conference Report) (pp. 349-375). Chicago: University of Chicago press.

Trachanas, E. \& Katrakilidis, C. (2013). The Dynamic Linkages of Fiscal and Current Account Deficits: New Evidence from Five Highly Indebted European Countries Accounting for Regime Shifts and Asymmetries. Economic Modelling 31, pp. 502-510.

Westerlund, J. (2007). Testing for error correction in panel data. Oxford Bulletin of Economics and Statistics 69:709-748.

Xie, Z \& Chen, S. W. (2014). Untangling the causal relationship between Government Budget and Current Account Deficits in OECD Countries: Evidence from Bootstrap Panel Granger Causality. International Review of Economics and Finance, 31, No. C, pp. 95-104. 
Table 1. Variables

\begin{tabular}{cl}
\hline \hline Variable & \multicolumn{1}{c}{ Description } \\
\hline \hline RGDP & Log of real GDP \\
\hline RGC & Log of real government consumption \\
\hline CA & Current Account as a percentage of GDP \\
\hline RIR & Short-term nominal interest rates adjusted for by inflation \\
\hline REER & $\begin{array}{l}\text { Log of real effective exchange rate based on manufacturing } \\
\text { consumer price index }\end{array}$ \\
\hline
\end{tabular}

Table 2. Cross Sectional Correlation (Pre-Estimation Test)

\begin{tabular}{lcccc}
\hline Variable & CD Test & p-value & $\begin{array}{c}\text { Average } \\
\text { correlation } \\
\text { coefficient }\end{array}$ & $\begin{array}{c}\text { Absolut } \\
\text { correlation } \\
\text { coefficient }\end{array}$ \\
\hline CA & 3.2 & 0.003 & 0.034 & 0.343 \\
FB & 2.54 & 0.011 & 0.029 & 0.318 \\
REER (In) & 32.31 & 0.000 & 0.271 & 0.485 \\
RGDP (In) & 103.23 & 0.000 & 0.880 & 0.880 \\
RIR & 80.44 & 0.000 & 0.674 & 0.676 \\
RGC (In) & 84.64 & 0.000 & 0.715 & 0.822 \\
\hline
\end{tabular}

NB: The average and absolute correlation coefficient are reported across $\mathrm{N} \times \mathrm{N}-1$ pairs of correlation. The Pesaran (2004) cross-sectional dependence test is distributed standard normal ( $C D \sim N(0,1)$, with the Null hypothesis of cross-section independence.

\section{Table 3 (a). Pesaran (2007) Panel Unit Root Test with Lag Bandwidth [0, 4]}

\begin{tabular}{|c|c|c|c|c|c|c|c|c|c|}
\hline & \multicolumn{5}{|c|}{ Current Account } & \multicolumn{4}{|c|}{ Real Effective Exchange Rate (In) } \\
\hline & \multicolumn{3}{|c|}{ Without trend } & \multicolumn{2}{|c|}{ With trend } & \multicolumn{2}{|c|}{ Without trend } & \multicolumn{2}{|c|}{ With trend } \\
\hline & lags & Zt-bar & $\mathrm{p}$-value & Zt-bar & $\begin{array}{c}p- \\
\text { value }\end{array}$ & Zt-bar & $\begin{array}{c}\mathrm{p}- \\
\text { value }\end{array}$ & Zt-bar & $\begin{array}{c}\mathrm{p}- \\
\text { value }\end{array}$ \\
\hline \multirow[t]{5}{*}{ in levels } & 0 & $-10.876 * * *$ & 0.000 & $-12.372 * * *$ & 0.000 & $-4.094 * * *$ & 0.000 & $-3.719 * * *$ & 0.000 \\
\hline & 1 & $-5.531 * * *$ & 0.000 & $-6.950 * * *$ & 0.000 & $-3.814 * * *$ & 0.000 & $-3.619 * * *$ & 0.000 \\
\hline & 2 & $-2.690 * * *$ & 0.004 & $-3.018 * * *$ & 0.001 & $-3.293 * * *$ & 0.000 & $-3.556 * * *$ & 0.000 \\
\hline & 3 & 2.266 & 0.988 & 4.571 & 1.000 & $-2.854 * * *$ & 0.002 & $-3.404 * * *$ & 0.000 \\
\hline & 4 & 0.796 & 0.787 & 2.453 & 0.993 & -1.457 & 0.073 & -1.412 & 0.079 \\
\hline \multirow[t]{5}{*}{ in 1st differences } & 0 & $-20.498^{* * *}$ & 0.000 & $-20.434 * * *$ & 0.000 & $-20.496 * * *$ & 0.000 & $-20.437 * * *$ & 0.000 \\
\hline & 1 & $-20.432 * * *$ & 0.000 & $-20.361 * * *$ & 0.000 & $-17.712^{* * *}$ & 0.000 & $-17.331^{* * *}$ & 0.000 \\
\hline & 2 & $-19.874 * * *$ & 0.000 & $-19.654 * * *$ & 0.000 & $-13.982 * * *$ & 0.000 & $-13.106 * * *$ & 0.000 \\
\hline & 3 & $-14.191 * * *$ & 0.000 & $-13.084 * * *$ & 0.000 & $-11.109 * * *$ & 0.000 & $-9.716^{* * *}$ & 0.000 \\
\hline & 4 & $-11.137 * * *$ & 0.000 & $-9.803 * * *$ & 0.000 & $-12.802 * * *$ & 0.000 & $-11.427 * * *$ & 0.000 \\
\hline
\end{tabular}

Note: The null hypothesis: Non-stationarity. *,**, *** denotes significance at $10 \%, 5 \%, 1 \%$ levels. 
Table 3 (b). Pesaran (2007) Panel Unit Root Test with Lag Bandwidth [0, 4]

\begin{tabular}{|c|c|c|c|c|c|c|c|c|c|}
\hline & & \multicolumn{4}{|c|}{ Real GDP (In) } & \multicolumn{4}{|c|}{ Real Interest Rate } \\
\hline & & \multicolumn{2}{|c|}{ Without trend } & \multicolumn{2}{|c|}{ With trend } & \multicolumn{2}{|c|}{ Without trend } & \multicolumn{2}{|c|}{ With trend } \\
\hline & lags & Zt-bar & $p$-value & Zt-bar & $p$-value & Zt-bar & p-value & Zt-bar & $p$-value \\
\hline \multirow[t]{5}{*}{ in levels: } & 0 & 1.203 & 0.886 & 1.823 & 0.966 & $-3.156 * * *$ & 0.001 & -1.164 & 0.122 \\
\hline & 1 & 1.657 & 0.951 & 2.230 & 0.987 & $-6.404 * * *$ & 0.000 & $-4.880 * * *$ & 0.000 \\
\hline & 2 & 0.917 & 0.820 & 1.650 & 0.951 & $-7.173 * * *$ & 0.000 & $-5.991 * * *$ & 0.000 \\
\hline & 3 & 0.395 & 0.654 & 1.388 & 0.917 & $-5.986 * * *$ & 0.000 & $-5.121 * * *$ & 0.000 \\
\hline & 4 & 1.181 & 0.881 & 2.119 & 0.983 & $-2.053^{* * *}$ & 0.000 & -0.588 & 0.278 \\
\hline \multirow[t]{5}{*}{ in 1st Differences: } & 0 & $-20.307^{* * *}$ & 0.000 & $-20.131 * * *$ & 0.000 & $-19.124 * * *$ & 0.000 & $-18.539 * * *$ & 0.000 \\
\hline & 1 & $-16.586 * * *$ & 0.000 & $-15.911 * * *$ & 0.000 & $-16.797 * * *$ & 0.000 & $-15.616^{* * *}$ & 0.000 \\
\hline & 2 & $-12.915^{* * *}$ & 0.000 & $-11.770 * * *$ & 0.000 & $-14.822^{* * *}$ & 0.000 & $-13.173^{* * *}$ & 0.000 \\
\hline & 3 & $-10.340 * * *$ & 0.000 & $-8.730 * * *$ & 0.000 & $-17.685^{* * *}$ & 0.000 & $-16.625 * * *$ & 0.000 \\
\hline & 4 & $-7.523 * * *$ & 0.000 & $-5.440 * * *$ & 0.000 & $-10.927^{* * *}$ & 0.000 & $-9.107 * * *$ & 0.000 \\
\hline
\end{tabular}

Note: The null hypothesis: Non-stationarity. ${ }^{*}, * *, * * *$ denotes significance at $10 \%, 5 \%, 1 \%$ levels.

Table 3 (c). Pesaran (2007) Panel Unit Root Test with Lag Bandwidth [0, 4]

\begin{tabular}{lccccc}
\hline & \multicolumn{5}{c}{ Real Gov. Consumption Expenditure(In) } \\
\hline & \multicolumn{4}{c}{ Without trend } & With trend \\
\cline { 2 - 5 } in levels: & lags & Zt-bar & p-value & Zt-bar & $p$-value \\
& 0 & 1.700 & 0.955 & 2.594 & 0.995 \\
& 1 & 3.173 & 0.999 & 4.615 & 1.000 \\
& 2 & 3.083 & 0.999 & 4.008 & 1.000 \\
in 1st Differences: & 3 & 3.676 & 1.000 & 4.391 & 1.000 \\
& 0 & $-19.889 * * *$ & 0.000 & $-19.839 * * *$ & 0.000 \\
& 1 & $-18.252^{* * *}$ & 0.000 & $-17.860 * * *$ & 0.000 \\
& 2 & $-16.879 * * *$ & 0.000 & $-16.290 * * *$ & 0.000 \\
& 3 & $-12.269 * * *$ & 0.000 & $-10.933^{* * *}$ & 0.000
\end{tabular}

Note: The null hypothesis: Non-stationarity. $*, * *, * * *$ denotes significance at $10 \%, 5 \%, 1 \%$ levels. 
Table 3 (d). Pesaran (2007) Panel Unit Root Test with Lag Bandwidth [0, 4]

\begin{tabular}{|c|c|c|c|c|c|}
\hline & \multirow[b]{3}{*}{ lags } & \multicolumn{4}{|c|}{ Fiscal Balance } \\
\hline & & \multicolumn{2}{|c|}{ Without trend } & \multicolumn{2}{|c|}{ With trend } \\
\hline & & Zt-bar & $p$-value & Zt-bar & $p$-value \\
\hline \multirow[t]{5}{*}{ in levels: } & 0 & $-10.970 * * *$ & 0.000 & $-12.532 * * *$ & 0.000 \\
\hline & 1 & $-5.410 * * *$ & 0.000 & $-6.791 * * *$ & 0.000 \\
\hline & 2 & $-2.968 * * *$ & 0.001 & $-3.551 * * *$ & 0.000 \\
\hline & 3 & 1.778 & 0.962 & 3.670 & 1.000 \\
\hline & 4 & 0.562 & 0.713 & 1.800 & 0.964 \\
\hline \multirow[t]{5}{*}{ in 1st Differences: } & 0 & $-20.498 * * *$ & 0.000 & $-20.434 * * *$ & 0.000 \\
\hline & 1 & $-20.401 * * *$ & 0.000 & $-20.318 * * *$ & 0.000 \\
\hline & 2 & $-19.643 * * *$ & 0.000 & $-19.218 * * *$ & 0.000 \\
\hline & 3 & $-14.847 * * *$ & 0.000 & $-13.587^{* * *}$ & 0.000 \\
\hline & 4 & $-11.591 * * *$ & 0.000 & $-10.160 * * *$ & 0.000 \\
\hline
\end{tabular}

Note: The null hypothesis: Non-stationarity. *, **, *** denotes significance at $10 \%, 5 \%, 1 \%$ levels. 
Table 4. Westerlund (2007) Panel Cointegration Test

\begin{tabular}{|c|c|c|c|c|c|c|c|c|}
\hline \multicolumn{9}{|c|}{ MODEL VARIABLES: CA and FB } \\
\hline & \multicolumn{4}{|c|}{ Constant } & \multicolumn{4}{|c|}{ Constant and trend } \\
\hline & Value & Z-value & P-value & Robust P-Value & Value & Z-value & P-value & Robust P-Value \\
\hline & \multicolumn{4}{|c|}{ Unrestricted (Average AIC selected lag length: 1.56) } & \multicolumn{4}{|c|}{$\begin{array}{c}\text { Unrestricted (Average AIC selected lag length: } \\
1.39 \text { ) }\end{array}$} \\
\hline \multirow[t]{2}{*}{ Gt } & -4.062 & -10.787 & 0.000 & 0.000 & -5.041 & -13.963 & 0.000 & 0.000 \\
\hline & -44.625 & -29.213 & 0.000 & 0.000 & -63.549 & -32.154 & 0.000 & 0.000 \\
\hline \multicolumn{9}{|l|}{$\mathrm{Ga}$} \\
\hline Pt & -20.625 & -14.568 & 0.000 & 0.0001 & -23.761 & -16.921 & 0.000 & 0.000 \\
\hline \multirow[t]{2}{*}{$\mathrm{Pa}$} & -45.979 & -39.897 & 0.000 & 0.000 & -55.485 & -32.212 & 0.000 & 0.001 \\
\hline & \multicolumn{4}{|c|}{ Fixed Short-run Dynamics } & \multicolumn{4}{|c|}{ Fixed Short-run Dynamics } \\
\hline \multirow[t]{2}{*}{ Gt } & -4.979 & -15.119 & 0.000 & 0.000 & -5.727 & -17.545 & 0.000 & 0.000 \\
\hline & -53.043 & -35.773 & 0.000 & 0.000 & -66.913 & -34.253 & 0.000 & 0.000 \\
\hline \multicolumn{9}{|l|}{$\mathrm{Ga}$} \\
\hline $\mathrm{Pt}$ & -20.625 & -14.568 & 0.000 & 0.000 & -23.761 & -16.921 & 0.000 & 0.000 \\
\hline \multirow[t]{5}{*}{$\mathrm{Pa}$} & -45.979 & -39.897 & 0.000 & 0.000 & -55.485 & -32.212 & 0.000 & 0.000 \\
\hline & \multicolumn{8}{|c|}{ MODEL VARIABLES: CA, FB and REER } \\
\hline & \multicolumn{4}{|c|}{ Constant } & \multicolumn{4}{|c|}{ Constant and trend } \\
\hline & Value & Z-value & P-value & Robust P-Value & Value & Z-value & P-value & Robust P-Value \\
\hline & \multicolumn{4}{|c|}{ Unrestricted (Average AIC selected lag length: 1.56) } & \multicolumn{4}{|c|}{$\begin{array}{c}\text { Unrestricted (Average AIC selected lag length: } \\
1.39 \text { ) }\end{array}$} \\
\hline \multirow[t]{2}{*}{ Gt } & -4.760 & -12.552 & 0.000 & 0.000 & -5.292 & -13.947 & 0.000 & 0.000 \\
\hline & -52.695 & -29.471 & 0.000 & 0.000 & -66.990 & -30.879 & 0.000 & 0.000 \\
\hline \multicolumn{9}{|l|}{ Ga } \\
\hline Pt & -23.233 & -15.461 & 0.000 & 0.000 & -24.942 & -16.891 & 0.000 & 0.000 \\
\hline \multirow[t]{2}{*}{$\mathrm{Pa}$} & -52.681 & -35.523 & 0.000 & 0.000 & -59.318 & -30.650 & 0.000 & 0.000 \\
\hline & \multicolumn{4}{|c|}{ Fixed Short-run Dynamics } & \multicolumn{4}{|c|}{ Fixed Short-run Dynamics } \\
\hline \multirow[t]{2}{*}{$\mathrm{Gt}$} & -5.397 & -15.490 & 0.000 & 0.000 & -5.934 & -17.183 & 0.000 & 0.000 \\
\hline & -57.747 & -32.888 & 0.000 & 0.000 & -68.575 & -31.797 & 0.000 & 0.000 \\
\hline \multicolumn{9}{|l|}{ Ga } \\
\hline Pt & -23.233 & -15.461 & 0.000 & 0.000 & -24.942 & -16.891 & 0.000 & 0.000 \\
\hline $\mathrm{Pa}$ & -52.681 & -35.523 & 0.000 & 0.000 & -59.318 & -30.650 & 0.000 & 0.060 \\
\hline
\end{tabular}


Table 5 (a). Estimation of Cointegration Coefficient

\begin{tabular}{|c|c|c|c|c|c|c|}
\hline \multicolumn{7}{|c|}{ Pesaran (2006) Common Correlated Effects Mean Group estimator } \\
\hline Wald c & & 4.34 & & & & \\
\hline Prob > & & 0.0372 & & & & \\
\hline Numbe & bs & 1,359 & & & & \\
\hline \multicolumn{7}{|c|}{ Mean Group type estimation } \\
\hline CA & Coef. & Std. Error & $\mathrm{z}$ & $P>|z|$ & {$[95 \%$ Conf. } & $\begin{array}{l}\text { 95\% Conf. } \\
\text { Interval] }\end{array}$ \\
\hline FB & .2085677 & .1001211 & 2.08 & 0.037 & .0123339 & .4048014 \\
\hline _CA & .8957657 & .3531424 & 2.54 & 0.011 & 203619 & 1.587 .912 \\
\hline _FB & .0258043 & .0846863 & 0.30 & 0.761 & -.1401779 & .1917864 \\
\hline _cons & .9593484 & 1.063 .535 & 0.90 & 0.367 & -1.125 .141 & 3.043 .838 \\
\hline \multicolumn{7}{|c|}{ Root Mean Squared Error (sigma): 2.6994} \\
\hline \multicolumn{7}{|c|}{ Cross-section averaged regressors are marked by the suffix: _CA, _BB respectively. } \\
\hline \multicolumn{7}{|c|}{ All coefficients present represent averages across groups } \\
\hline \multicolumn{7}{|c|}{ Coefficient averages computed as unweighted means } \\
\hline
\end{tabular}

Table 5 (b). Estimation of Cointegration Coefficient

\begin{tabular}{|c|c|c|c|c|c|c|}
\hline \multicolumn{7}{|c|}{ Pesaran (2006) Common Correlated Effects Mean Group estimator } \\
\hline \multicolumn{2}{|c|}{ Wald chi2(1) } & 6.41 & & & & \\
\hline \multicolumn{2}{|c|}{ Prob > chi2 } & 0.0406 & & & & \\
\hline \multicolumn{2}{|c|}{ Number of obs } & 1,358 & & & & \\
\hline \multicolumn{7}{|c|}{ Mean Group type estimation } \\
\hline CA & Coef. & Std. Error & z & $P>|z|$ & [95\% Conf. & $\begin{array}{l}\text { 95\% Conf. } \\
\text { Interval] }\end{array}$ \\
\hline FB & .2441189 & .096441 & 2.53 & 0.011 & .055098 & 1.007.327 \\
\hline REER & -.1027841 & .1334112 & -0.77 & 0.441 & -.3642653 & -.0002813 \\
\hline _CA & .9929852 & .368058 & 2.70 & 0.007 & .2716048 & .003458 \\
\hline FB & -.0963406 & .0903908 & -1.07 & 0.287 & -.2735034 & .002059 \\
\hline _REER & .0431855 & .2000155 & 0.22 & 0.829 & -.3488377 & -.0005965 \\
\hline _cons & 6.220 .446 & 9.173 .248 & 0.68 & 0.498 & -1.175 .879 & .6427124 \\
\hline \multicolumn{7}{|c|}{ Root Mean Squared Error (sigma): 2.6994} \\
\hline \multicolumn{7}{|c|}{$\begin{array}{l}\text { Cross-section averaged regressors are marked by the suffix: } \\
\text { All coefficients present represent averages across groups }\end{array}$} \\
\hline \multicolumn{7}{|c|}{ Coefficient averages computed as unweighted means } \\
\hline
\end{tabular}


Table 6. Pairwise Granger Causality Test Results

(a)

Pairwise Granger Causality Test

Sample: 1995Q1-2018Q2

Lags: 2

Null hypothesis:

Obs F-Statistic Prob.

Current Account does not Granger cause Budget Balance

1323

252.374

2.E-11

Budget Balance does not Granger cause Budget Balance

489.097

0.0077

(b)

Pairwise Granger Causality Test

Sample: 1995Q1-2018Q2

Lags: 4

Null hypothesis:

Obs F-Statistic Prob.

CA does not Granger cause FB

1287

$976.346 \quad 9 . \mathrm{E}-08$

FB does not Granger cause CA

369.056

0.0054

(c)

Pairwise Granger Causality Test

Sample: 1995Q1-2018Q2

Lags: 8

Null hypothesis:

Obs F-Statistic Prob.

Current Account does not Granger cause Budget Balance

1215

$498.989 \quad 4 . \mathrm{E}-06$

Budget Balance does not Granger cause Budget Balance

$327.012 \quad 0.0011$


Table 7 (a). Panel Regression for CA

\begin{tabular}{|c|c|c|c|c|c|c|}
\hline & $\begin{array}{c}\text { Pooled OLS } \\
\text { (Without } \\
\text { Dummy) }\end{array}$ & $\begin{array}{c}\text { Pooled } \\
\text { OLS (With } \\
\text { Dummy) }\end{array}$ & $\begin{array}{c}\text { Fixed } \\
\text { effect } \\
\text { (Without } \\
\text { Dummy) }\end{array}$ & $\begin{array}{c}\text { Fixed effect } \\
\text { (With } \\
\text { Dummy) }\end{array}$ & $\begin{array}{c}\text { Random } \\
\text { effect } \\
\text { (Without } \\
\text { Dummy) }\end{array}$ & $\begin{array}{l}\text { Random } \\
\text { effect } \\
\text { (With } \\
\text { Dummy) }\end{array}$ \\
\hline $\mathrm{C}$ & $\begin{array}{c}-0.8420 \\
(1.452)\end{array}$ & $\begin{array}{l}-1.648 \\
(1.433)\end{array}$ & $\begin{array}{l}6.8610 \\
(1.467)\end{array}$ & $\begin{array}{l}6.6217 \\
(1.479)\end{array}$ & $\begin{array}{l}6.8447 \\
(1.592)\end{array}$ & $\begin{array}{c}6.369 \\
(1.553)\end{array}$ \\
\hline FB & $\begin{array}{c}0.4976 * * * \\
(0.0315)\end{array}$ & $\begin{array}{c}0.6510 * * * \\
(0.0504)\end{array}$ & $\begin{array}{c}0.1573 * * * \\
(0.0249)\end{array}$ & $\begin{array}{c}0.2683 * * * \\
(0.0401)\end{array}$ & $\begin{array}{c}0.1681 * * * \\
(0.0248)\end{array}$ & $\begin{array}{c}0.2865 * * * \\
(0.0399)\end{array}$ \\
\hline REER & $\begin{array}{c}0.0225 \\
(0.0144)\end{array}$ & $\begin{array}{c}0.0224 \\
(0.0142)\end{array}$ & $\begin{array}{c}-0.0636 * * * \\
(0.0147)\end{array}$ & $\begin{array}{c}-0.0626 * * * \\
(0.0147)\end{array}$ & $\begin{array}{c}-0.0596 * * * \\
(0.0145)\end{array}$ & $\begin{array}{c}- \\
0.0566 * * * \\
(0.0145)\end{array}$ \\
\hline$(\mathrm{FB}) * \mathrm{DUMMY}$ & & $\begin{array}{c}-0.1635 * * \\
(0.0648)\end{array}$ & & $\begin{array}{c}-0.1401 * * * \\
(0.0489)\end{array}$ & & $\begin{array}{c}- \\
0.1412 * * * \\
(0.0489)\end{array}$ \\
\hline (REER)*DUMMY & & $\begin{array}{c}0.0179 * * * \\
(0.0032)\end{array}$ & & $\begin{array}{c}0.0034 \\
(0.0024)\end{array}$ & & $\begin{array}{l}0.0040 * \\
(0.0024)\end{array}$ \\
\hline $\mathrm{N}$ & 1358 & 1358 & 1358 & 1358 & 1358 & 1358 \\
\hline Adj R2 & 0.1560 & 0.1932 & 0.5944 & 0.6010 & 0.0443 & 0.0576 \\
\hline
\end{tabular}

Standard errors are in parenthesis below each coefficient estimate. *,**,*** denote statistical significance at the 10 , 5 , and 1 percent level, respectively. 
Table 7 (b). Hausman Test Results

Correlated Random Effects - Hausman Test

Test cross-section random effects

\begin{tabular}{|c|c|c|c|c|}
\hline \multicolumn{2}{|l|}{ Test Summary } & \multirow{2}{*}{$\begin{array}{c}\text { Chi-Sq. Statistic } \\
26.335 .543\end{array}$} & \multirow{2}{*}{$\begin{array}{c}\text { Chi-Sq. d.f. } \\
2\end{array}$} & \multirow{2}{*}{$\begin{array}{l}\text { Prob. } \\
0.0000\end{array}$} \\
\hline Cross-section random & & & & \\
\hline \multicolumn{5}{|c|}{ Cross-section random effects test comparisons: } \\
\hline Variable & Fixed & Random & $\operatorname{Var}($ Diff.) & Prob. \\
\hline FB & 0.157331 & 0.168116 & 0.000004 & 0.0000 \\
\hline REER & -0.063632 & -0.059635 & 0.000005 & 0.0634 \\
\hline
\end{tabular}

Total panel (unbalanced) observations: 1358

$\begin{array}{lrrrr}\text { Variable } & \text { Coefficient } & \text { Std. Error } & \text { t-Statistic } & \text { Prob. } \\ \text { C } & 6.869 .802 & 1.467 .160 & 4.682 .379 & 0.0000 \\ \text { FB } & 0.157331 & 0.024885 & 6.322 .226 & 0.0000 \\ \text { REER } & -0.063632 & 0.014705 & -4.327 .332 & 0.0000\end{array}$

Effects Specification

Cross-section fixed (dummy variables)

\begin{tabular}{lclr} 
R-squared & 0.600086 & Mean dependent var & 0.118626 \\
Adjusted R-squared & 0.594407 & S.D. dependent var & 5.694 .647 \\
S.E. of regression & 3.626 .703 & Akaike info criterion & 5.429 .143 \\
Sum squared resid & 17598.68 & Schwarz criterion & 5.505 .929 \\
Log likelihood & -3.666 .388 & Hannan-Quinn criter. & 5.457 .891 \\
F-statistic & 1.056 .695 & Durbin-Watson stat & 1.198 .946 \\
Prob(F-statistic) & 0.000000 & & \\
\hline
\end{tabular}

Null: Random effect method is appropriate. 
Table 8 (a). Panel Regression for CA, dynamic model

\begin{tabular}{lccc}
\hline & Pooled OLS & Fixed Effects & Random Effects \\
\hline Constant & 0.35205 & 4.9333 & 0.3520 \\
& $(1.0178)$ & $(1.3660)$ & $(0.9291)$ \\
CA(-1) & $0.8281 * * *$ & $0.5303 * * *$ & $0.8281^{* * *}$ \\
FB & $(0.0282)$ & $(0.0394)$ & $(0.0257)$ \\
& $0.1283 * * *$ & $0.1117 * * *$ & $0.1283 * * *$ \\
REER & $(0.0400)$ & $(0.0394)$ & $(0.0366)$ \\
& -0.0026 & $-0.0476 * * *$ & $-0.0026^{*}$ \\
CA(-1)*DUMMY & $(0.0100)$ & $(0.0136)$ & $(0.0092)$ \\
& $-0.2281 * * *$ & $-0.2271 * * *$ & $-0.2281 * * *$ \\
(FB)*DUMMY & $(0.0384)$ & $(0.0373)$ & $(0.0351)$ \\
& 0.0744 & 0.0425 & 0.0744 \\
(REER)*DUMMY & $(0.0506)$ & $(0.0491)$ & $(0.0462)$ \\
& $0.0094 * * *$ & $0.0056 * *$ & $0.0094 * * *$ \\
N & $(0.0024)$ & $(0.0022)$ & $(0.0022)$ \\
Adj R2 & 1346 & 1346 & 1346 \\
\hline
\end{tabular}

Standard errors are in parenthesis below each coefficient estimate. $* * *, * * *$ denote statistical significance at the 10 , 5 , and 1 percent level, respectively.

Table 8 (b). Hausman Test Results

\section{Correlated Random Effects - Hausman Test}

Test cross-section random effects

Test Summary

Chi-Sq. Statistic

Chi-Sq. d.f.

Prob.

Cross-section random

284.028 .564

6

0.0000

\begin{tabular}{|c|c|c|c|c|}
\hline \multicolumn{5}{|c|}{ Cross-section random effects test comparisons: } \\
\hline Variable & Fixed & Random & Var(Diff.) & Prob. \\
\hline $\mathrm{CA}(-1)$ & 0.530335 & 0.828139 & 0.000420 & 0.0000 \\
\hline FB & 0.111683 & 0.128296 & 0.000213 & 0.0685 \\
\hline REER & -0.047564 & -0.002613 & 0.000099 & 0.0000 \\
\hline CA(-1)*DUMMY & -0.227061 & -0.228145 & 0.000168 & 0.9333 \\
\hline$(\mathrm{FB}) * \mathrm{DUMMY}$ & 0.042545 & 0.074369 & 0.000358 & 0.0926 \\
\hline (REER)*DUMMY & 0.005613 & 0.009411 & 0.000000 & 0.0000 \\
\hline
\end{tabular}


Table A1. Descriptive Statistics - individual samples

\begin{tabular}{lcccccc}
\hline & CAB & FB & REER & RGDP & RGCE & RIR \\
\hline Mean & 0.265727 & -2.446 .098 & 4.592 .525 & 11,55499 & 3.686 .196 & 0.614822 \\
Median & -0.300000 & -2.300 .000 & 4.600 .061 & 11,26029 & 3.900 .051 & 0.376367 \\
Maximum & 2.210 .000 & 1.100 .000 & 4.885 .861 & 13,86797 & 8.143 .792 & 6.996 .970 \\
Minimum & -2.100 .000 & -4.180 .000 & 4.176 .435 & 8,64317 & -0.132878 & -4.658 .885 \\
Std. Dev. & 5.729 .158 & 4.640 .513 & 0.097557 & 1,34218 & 1.656 .916 & 1.907 .439 \\
Skewness & 0.243321 & -1.529 .347 & -0.693066 & -0.069886 & 0.465727 & 0.483932 \\
Kurtosis & 3.844 .510 & 1.233 .360 & 6.069 .419 & 1.843 .117 & 3.953 .616 & 2.910 .777 \\
\hline Jarque-Bera & 5.870 .314 & 5.257 .711 & 7.906 .802 & 93,24344 & 1.230 .566 & 5.782 .486 \\
Probability & 0.000000 & 0.000000 & 0.000000 & 0.000000 & 0.000000 & 0.000000 \\
Sum & 3.940 .727 & -3.199 .496 & 7.683 .295 & 19042.62 & 6.126 .458 & 9.031 .738 \\
Sum Sq. Dev. & 48644.06 & 28145.41 & 1.591 .315 & $2.966,980$ & 4.560 .060 & 5.341 .060 \\
Observations & 1483 & 1308 & 1673 & 1648 & 1662 & 1469 \\
\hline
\end{tabular}

Table A2. Descriptive Statistics - common samples

\begin{tabular}{ccccccc}
\hline & CA & FB & REER & RGDP & RGCE & RIR \\
\hline Mean & -0.046925 & -2.542 .718 & 4.596 .629 & 11,49935 & 3.880 .431 & 0.505327 \\
Median & -0.900000 & -2.400 .000 & 4.601 .748 & 10,98624 & 3.990 .276 & 0.233027 \\
Maximum & 2.210 .000 & 1.100 .000 & 4.885 .861 & 13,86797 & 8.143 .792 & 6.996 .970 \\
Minimum & -2.100 .000 & -4.180 .000 & 4.176 .435 & 9.000 .594 & 0.251720 & -4.658 .885 \\
Std. Dev. & 5.911 .416 & 4.681 .296 & 0.107069 & 1.363 .595 & 1.718 .700 & 1.887 .201 \\
Skewness & 0.174482 & -1.580 .118 & -0.773718 & 0.065555 & 0.546656 & 0.577607 \\
Kurtosis & 3.481 .397 & 1.270 .774 & 5.729 .189 & 1.731 .733 & 3.793 .066 & 3.151 .999 \\
\hline Jarque-Bera & 1.772 .019 & 5.224 .391 & 4.933 .819 & 81,48780 & 9.144 .230 & 6.805 .090 \\
Probability & 0.000142 & 0.000000 & 0.000000 & 0.000000 & 0.000000 & 0.000000 \\
Sum & -5.645 .102 & -3.058 .890 & 5.529 .745 & 13833.71 & 4.668 .158 & 6.079 .084 \\
Sum Sq. Dev. & 42003.69 & 26341.27 & 1.377 .950 & $2.234,99$ & 3.550 .623 & 4.280 .958 \\
Observations & 1203 & 1203 & 1203 & 1203 & 1203 & 1203 \\
\hline
\end{tabular}


Table A3. Correlation among the variables used in the models

\begin{tabular}{lcccccc}
\hline & CA & FB & REER & RGDP & RGCE & RIR \\
\hline CA & 1.000 & & & & & \\
FB & 0.411 & 1.000 & & & & \\
REER & 0.061 & 0.009 & 1.000 & & & \\
RGDP & 0.238 & 0.061 & 0.260 & 1.000 & & \\
RGCE & -0.043 & 0.006 & 0.181 & 0.224 & 1.000 & \\
RIR & -0.046 & 0.064 & 0.048 & -0.009 & 0.108 & 1.000 \\
\hline
\end{tabular}

FIGURE A1 - The Fiscal balance (FB) and Current account balance (CAB) of Individual countries for the period 1995Q1-2018Q1

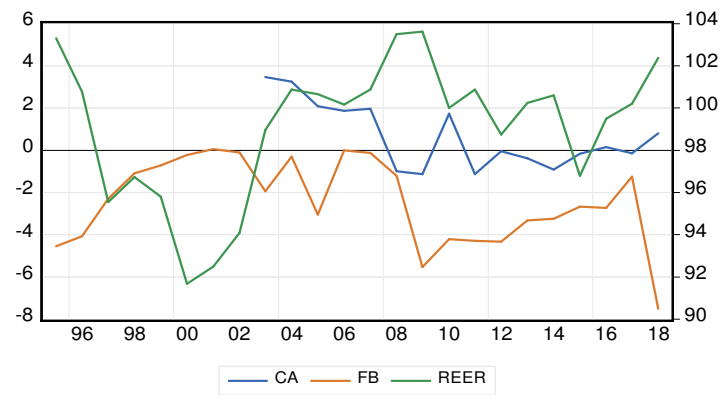

BEL

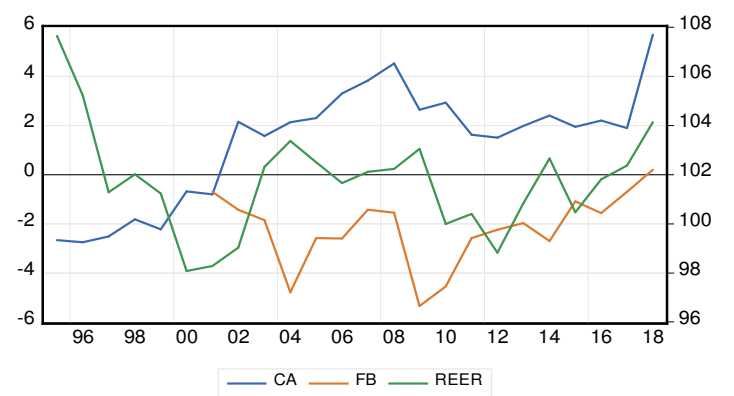

OST

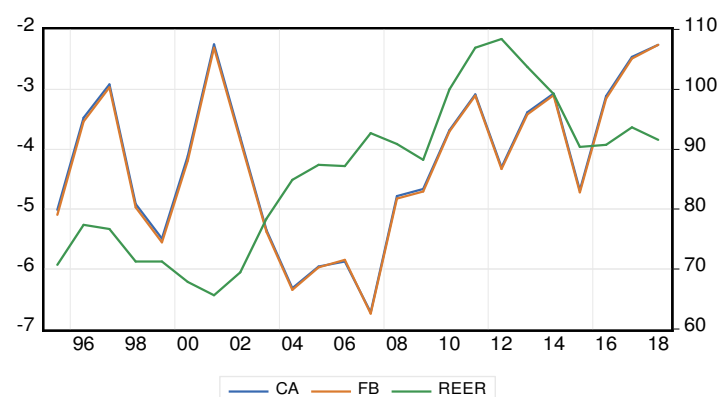

AUS

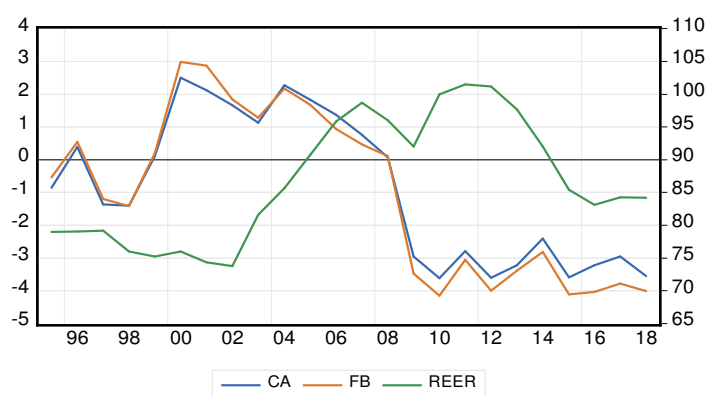

CAN 


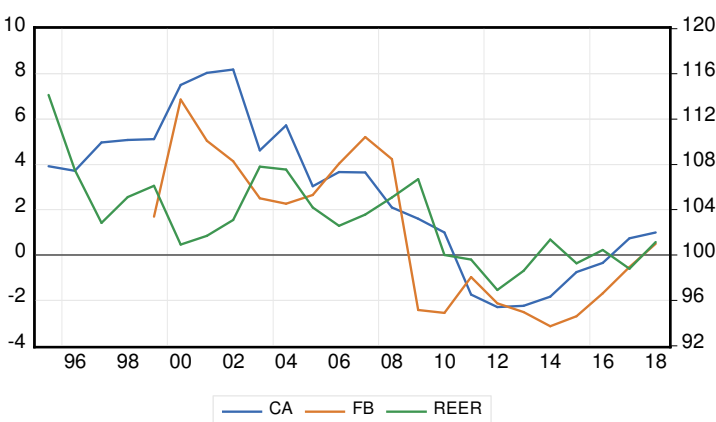

FIN

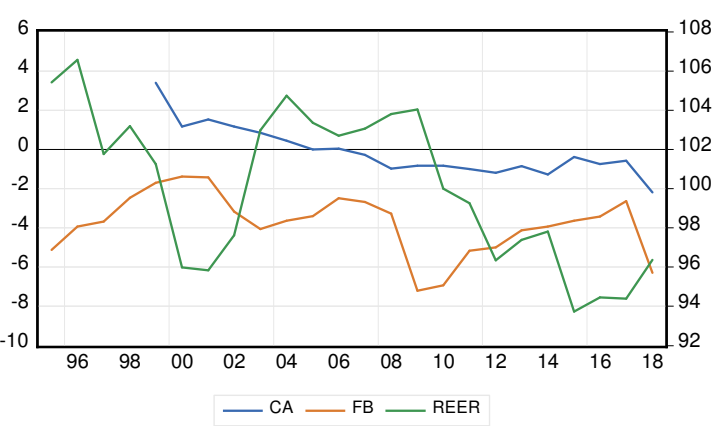

FRA

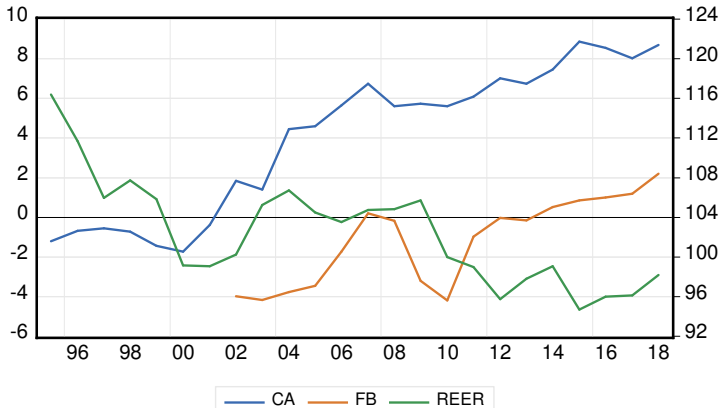

DEU

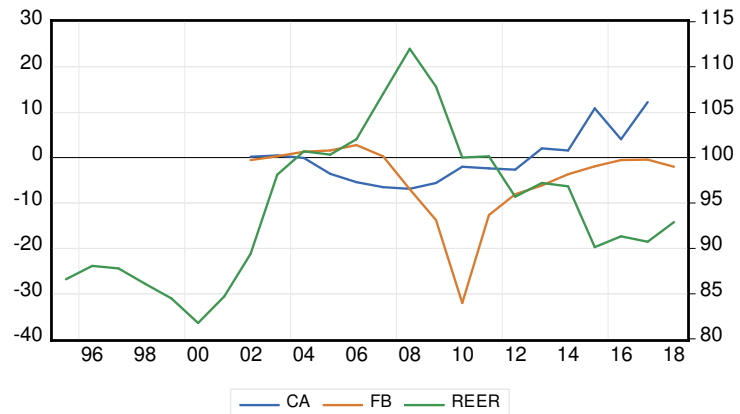

IRE

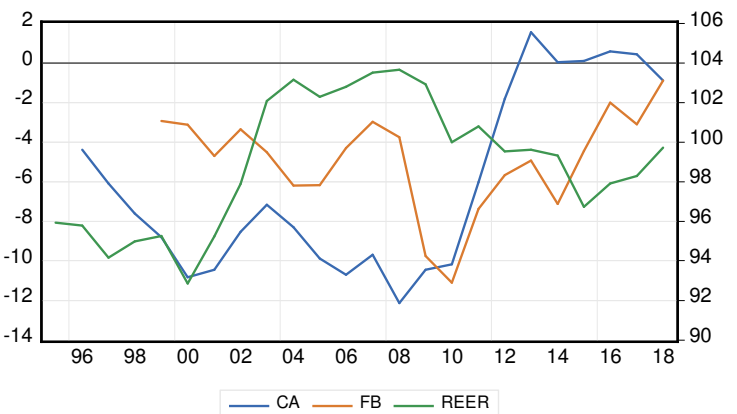

POR

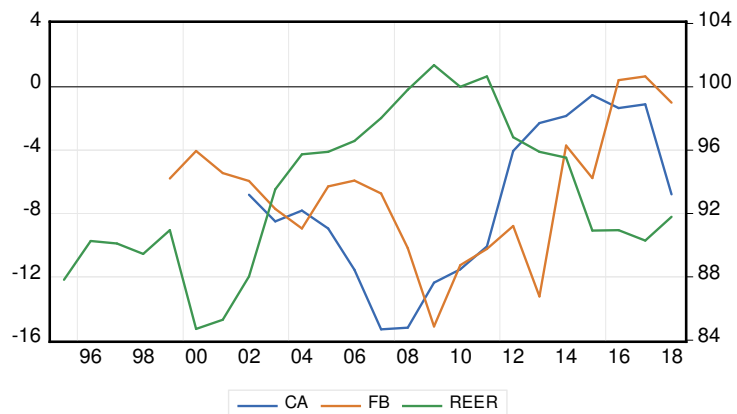

GRE 


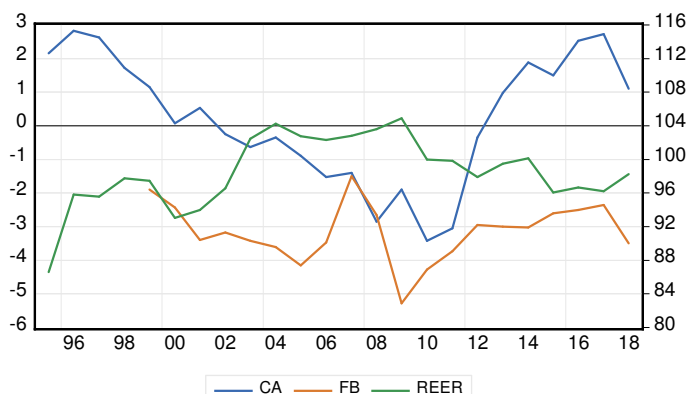

ITA

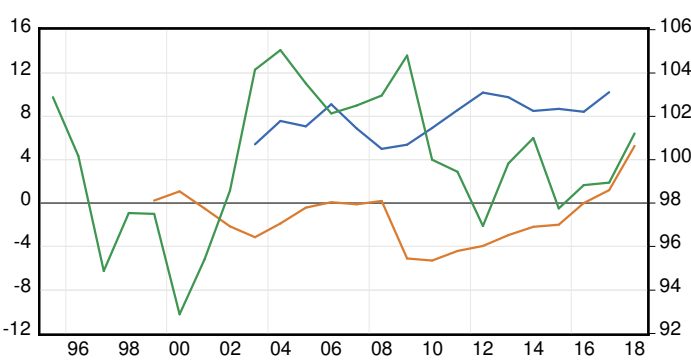

- CA — FB — REER

NED

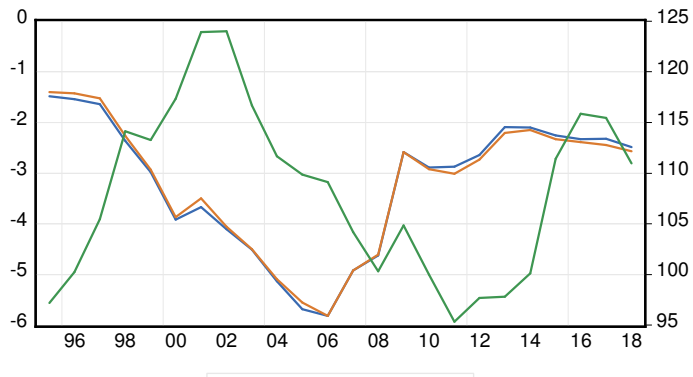

USA

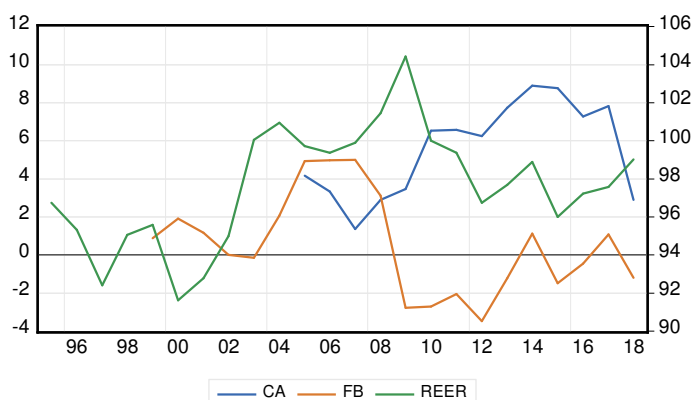

DEN

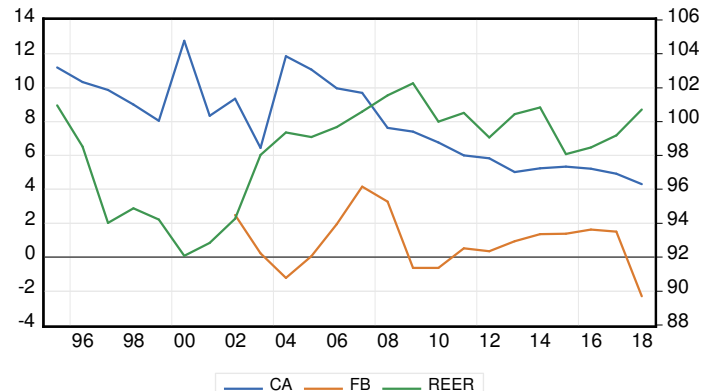

\section{LUX}

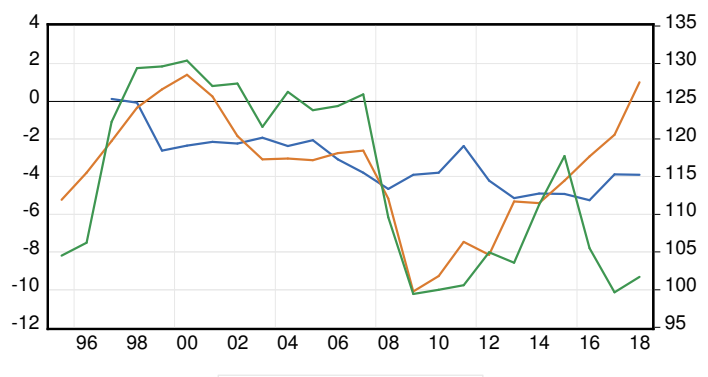

UKA

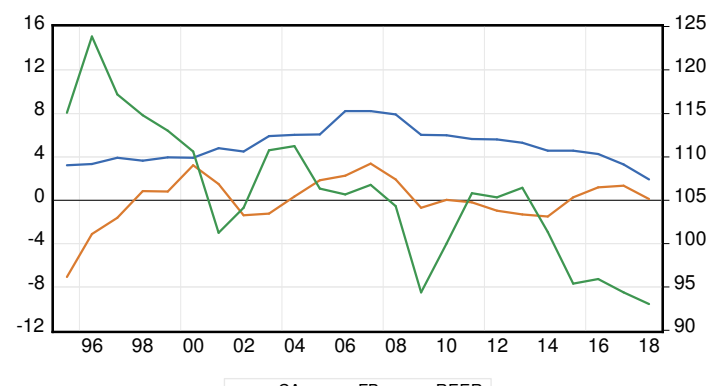

SWE

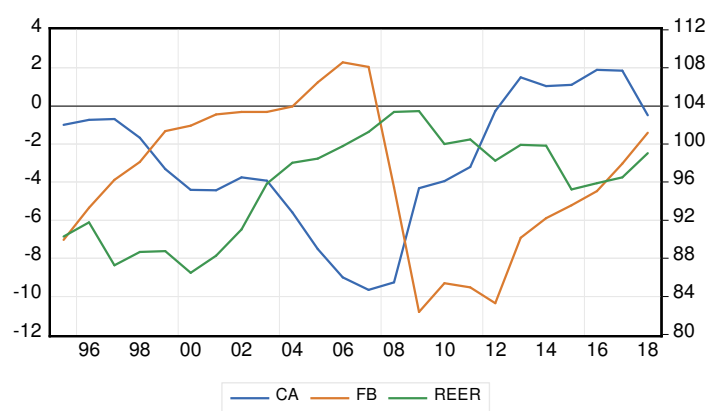

ESP 


\section{Appendix B}

Table B1. Model A Variance Decomposition (\%)

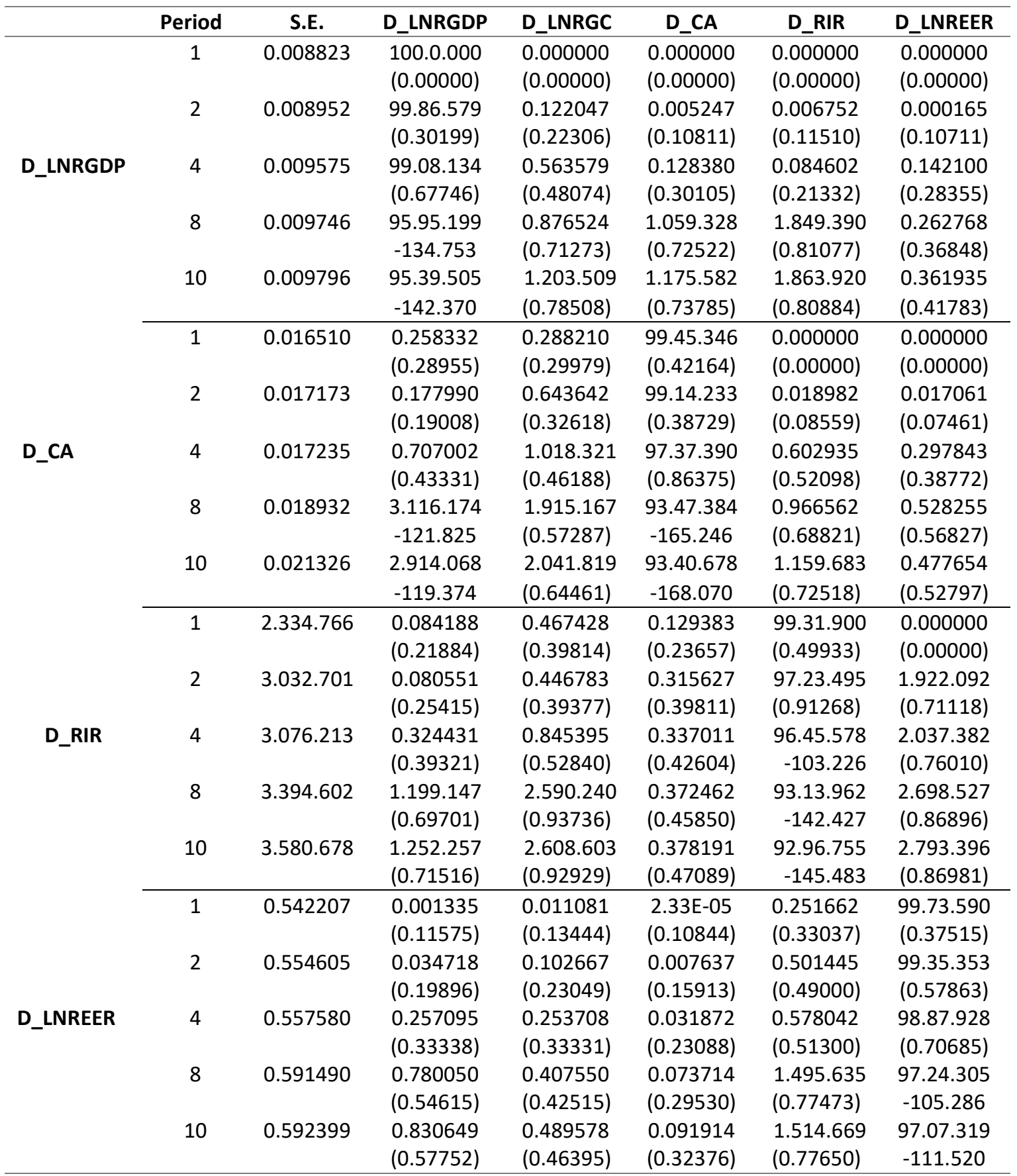

Cholesky Ordering: D_LNRGDP D_FB D_CA D_RIR D_LNREER

Standard Errors: Monte Carlo (500 repetitions) 
Table B2. Model B Variance Decomposition (\%)

\begin{tabular}{|c|c|c|c|c|c|c|c|}
\hline & Period & S.E. & D_LNRGDP & D_FB & D_CA & D_RIR & D_LNREER \\
\hline & 1 & 0.008522 & 100,0000 & 0.000000 & 0.000000 & 0.000000 & 0.000000 \\
\hline & & & $(0.00000)$ & $(0.00000)$ & $(0.00000)$ & $(0.00000)$ & $(0.00000)$ \\
\hline & 2 & 0.008849 & 98.51183 & 0.137248 & 1.328 .308 & 0.004625 & 0.017986 \\
\hline & & & $(0.94711)$ & $(0.33678)$ & $(0.83812)$ & $(0.18228)$ & (0.19425) \\
\hline \multirow[t]{10}{*}{ D_LNRGDP } & 4 & 0.009639 & 97.05625 & 0.126914 & 2.500 .587 & 0.173272 & 0.142975 \\
\hline & & & -142.566 & $(0.38832)$ & -121.421 & $(0.41981)$ & $(0.40310)$ \\
\hline & 8 & 0.009928 & 93,27862 & 0.818694 & 4.183.166 & 1.465 .373 & 0.254147 \\
\hline & & & -198.941 & $(0.86353)$ & -148.452 & $(0.91042)$ & (0.61257) \\
\hline & 10 & 0.010028 & 92.00631 & 1.635 .532 & 4.121 .362 & 1.848 .997 & 0.387800 \\
\hline & & & -206.635 & -106.563 & -150.566 & -106.855 & (0.71491) \\
\hline & 1 & 2.513 .754 & 0.517354 & 0.344752 & 99.137890 & 0.000000 & 0.000000 \\
\hline & & & $(0.50839)$ & $(0.44449)$ & (0.65059) & $(0.00000)$ & $(0.00000)$ \\
\hline & 2 & 3.151 .446 & 1.612 .774 & 0.218603 & 98.11850 & 0.003379 & 0.053396 \\
\hline & & & -107.757 & (0.36149) & -116.401 & (0.14039) & (0.17588) \\
\hline \multirow[t]{10}{*}{ D_CA } & 4 & 3.203 .428 & 3.054 .671 & 0.462804 & 95.700560 & 0.476455 & 0.305510 \\
\hline & & & -151.093 & $(0.62946)$ & -179.240 & $(0.66722)$ & (0.54489) \\
\hline & 8 & 3.301 .017 & 5.869 .493 & 0.884842 & 92.218500 & 0.670922 & 0.356243 \\
\hline & & & -181.096 & $(0.75276)$ & -216.098 & $(0.82325)$ & (0.62507) \\
\hline & 10 & 3.479 .461 & 5.813 .636 & 1.128 .990 & 91.608370 & 1.066 .346 & 0.382654 \\
\hline & & & -185.950 & $(0.92981)$ & -234.202 & $(0.97034)$ & (0.72367) \\
\hline & 1 & 2.254 .831 & 0.074186 & 0.650799 & 0.127315 & 99.1477 & 0.000000 \\
\hline & & & $(0.24326)$ & $(0.61973)$ & $(0.31100)$ & $(0.72759)$ & $(0.00000)$ \\
\hline & 2 & 2.831.973 & 0.070632 & 0.671065 & 0.205250 & 95.67146 & 3.381 .597 \\
\hline & & & (0.30969) & $(0.63136)$ & $(0.44730)$ & -165.119 & -140.897 \\
\hline \multirow[t]{10}{*}{ D_RIR } & 4 & 2.877.227 & 2.076 .553 & 0.692117 & 0.256250 & 93.29258 & 3.682 .500 \\
\hline & & & -110.496 & (0.67299) & (0.54693) & -197.150 & -150.946 \\
\hline & 8 & 3.230 .040 & 2.604 .368 & 1.229 .986 & 0.421308 & 90.90361 & 4.840 .732 \\
\hline & & & -134.140 & $(0.96751)$ & (0.72193) & -234.081 & -167.251 \\
\hline & 10 & 3.267 .703 & 3.023 .348 & 1.587 .004 & 0.428814 & 89.90105 & 5.059 .788 \\
\hline & & & -140.048 & -114.330 & $(0.76415)$ & -235.690 & -168.453 \\
\hline & 1 & 0.522548 & 0.094473 & 0.147131 & $2.79 \mathrm{E}-05$ & 2.654 .237 & 9.710 .413 \\
\hline & & & $(0.28483)$ & $(0.36288)$ & $(0.17000)$ & -116.907 & -128.019 \\
\hline & 2 & 0.538822 & 0.176031 & 0.140097 & 0.014211 & 2.713 .569 & 96.95 .609 \\
\hline & & & $(0.41220)$ & $(0.38484)$ & $(0.25360)$ & -121.085 & -137.706 \\
\hline \multirow[t]{6}{*}{ D_LNREER } & 4 & 0.546232 & 0.194266 & 0.191842 & 0.032833 & 2.915 .077 & 96.66 .598 \\
\hline & & & $(0.50162)$ & $(0.53013)$ & $(0.40782)$ & -124.989 & -152.401 \\
\hline & 8 & 0.597800 & 0.876063 & 0.451038 & 0.166497 & 4.203 .379 & 9.430 .302 \\
\hline & & & $(0.83803)$ & $(0.68024)$ & $(0.62746)$ & -155.466 & -204.488 \\
\hline & 10 & 0.602824 & 0.994145 & 0.600089 & 0.197912 & 4.327.141 & 93.88 .071 \\
\hline & & & $(0.90531)$ & $(0.80910)$ & $(0.68468)$ & -156.382 & -212.530 \\
\hline
\end{tabular}

Cholesky Ordering: D_LNRGDP D_FB D_CA D_RIR D_LNREER

Standard Errors: Monte Carlo (500 repetitions) 